\title{
Disability-free life expectancy: comparison of sources and small area estimates in England, 2006-08
}

Michael P Smith, Olugbenga Olatunde and Chris White Office for National Statistics

\section{Abstract}

\section{Background}

Health expectancies (HEs) at sub-national geographies or by clusters of areas defined by relative deprivation are important tools to monitor inequalities in health. Previously, analyses have had limited usefulness due to a lack of timeliness or local relevance caused by limitations on the frequency or coverage of survey data. Here we explore the potential of the Annual Population Survey (APS) to provide robust estimates of disability-free life expectancy (DFLE) for men and women by clusters of area deprivation, English regions and local authority districts (LAs) in the period 2006-08.

\section{Methods}

DFLE estimates for the UK were compared using the prevalence of limiting long-standing illness (LLSI) calculated using data from the APS and from the General Lifestyle Survey (GLF) covering Great Britain and equivalent data from the Continuous Household Survey (CHS) covering Northern Ireland, aggregated over the period 2006-08. The further use of APS data for England enabled the calculation of estimates of DFLE at age 16 and at age 65 for men and women by area deprivation quintiles (each quintile comprises a fifth of areas ranked according to their relative deprivation), English regions and LAs in order to measure inequality in DFLE between these population groupings.

\section{Results}

The prevalence of LLSI and estimates of DFLE at national level were broadly comparable using APS and GLF/CHS data. Substantial inequality in DFLE was present between clusters of areas defined by relative deprivation and between English regions and LAs. The scale of inequality increased markedly with each finer geographical scale analysed. 


\section{Conclusions}

The APS is a viable data source to provide LLSI data for use in DFLE estimation across a range of areas and clusters of area deprivation. While increasingly fine-grained analysis decreases statistical precision, it is possible to detect clear differences between areas within regions and in making comparisons with the England average. The estimates presented here provide scope to set benchmarks for assessing the impact of interventions designed to reduce inequality in DFLE beyond the period 2006-08. 


\section{Contents}

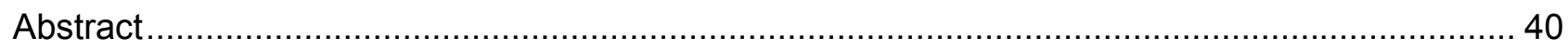

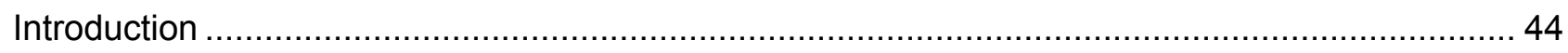

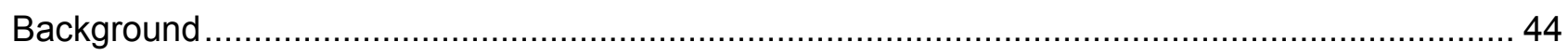

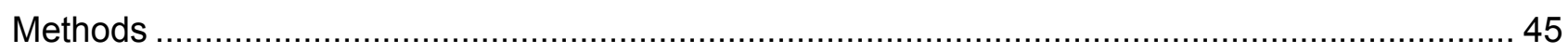

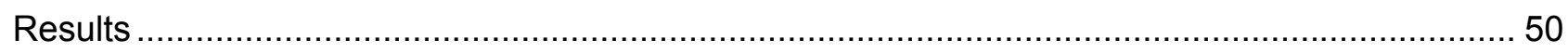

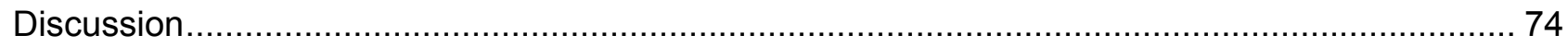

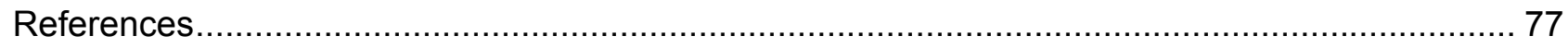

\section{List of Figures}

Figure 1 LE and DFLE for men at age 16: by IMD 2007 quintile, 2006-08 .......................55

Figure 2 LE and DFLE for men at age 65: by IMD 2007 quintile, 2006-08 ..........................56

Figure 3 LE and DFLE for women at age 16: by IMD 2007 quintile, 2006-08 ....................57

Figure 4 LE and DFLE for women at age 65: by IMD 2007 quintile, 2006-08.....................58

Figure 5 DFLE for men at age 16: by local authority district, 2006-08 ................................. 64

Figure 6 DFLE for men aged 16: by local authority district, 2006-08 ...................................6

Figure 7 DFLE for men at age 16: by local authority district and English region, 2006-08 .....67

Figure $8 \quad$ DFLE for women at age 16: by local authority district, 2006-08.........................69

Figure 9 DFLE for women aged 16: by local authority district, 2006-08 .............................71

Figure 10 DFLE for women at age 16: by local authority district and English region, 2006-08.72 


\section{List of Tables}

Table 1 Sample size and weighted prevalence of LLSI in adults (16 years and above); by source, country and sex, 2006-08.

Table 2 LE and DFLE for men at age 16 and at age 65; by survey source and country; 200608

Table 3 LE and DFLE for women at age 16 and age 65 ; by survey source and country; 2006-08

Table 4 Prevalence of limiting long-standing illness in England: by area deprivation quintile, 2006-08.

Table $5 \quad$ LE and DFLE for men at age 16: by English region, 2006-08 ….........................59

Table $6 \quad$ LE and DFLE for men at age 65: by English region, 2006-08 .............................60

Table $7 \quad$ LE and DFLE for women at age 16: by English region, 2006-08 .........................61

Table 8 LE and DFLE for women at age 65: by English region, 2006-08 ............................62

Table 9 Summary statistics of DFLE for men aged 16: by local authority district, 2006-08 ...65

Table 10 LE and DFLE for men at age 16: bottom and top 10 local authority districts ranked by

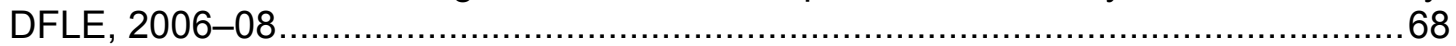

Table 11 Summary statistics of DFLE for women aged 16: by local authority districts, 2006-08 .70

Table 12 LE and DFLE for women at age 16: bottom and top 10 local authority districts ranked by DFLE, 2006-08. 


\section{Introduction}

Disability-free life expectancy (DFLE) is an estimation of the length of time that an individual can expect to live free from a limiting long-standing illness or disability, and therefore adds a qualitative dimension to measures of life expectancy (LE). The Office for National Statistics (ONS) routinely reports estimates of DFLE for males and females at birth and at age 65 in the UK and constituent countries; see for example ONS 2010. There is, however, a significant demand for robust estimates of DFLE at lower level geographies - for example, local authority districts (LAs) - to support the targeting of healthcare resources to those populations in most need and to monitor changes in health outcomes over time.

\section{Background}

Health inequalities have enormous social and economic costs. The recent Strategic Review of Health Inequalities in England post-2010 (Marmot, 2010) clearly highlights these and illustrates the likely benefits that would be realised if everyone experienced the same health as those in the most advantaged areas. The Review makes a compelling case for monitoring these inequalities more frequently at sub-national geographical scales to determine whether these inequalities, and their associated social and economic costs, are narrowing, persisting or widening over time in order to inform the effects of policy responses designed to improve the health outcomes of the disadvantaged and thereby reduce the inequality gap.

Health expectancies (HEs) are important outcome measures to monitor; a substantial body of literature demonstrates sizeable statistically significant geographical differences in these measures, strongly associated with the relative level of deprivation experienced by the area (Bajekal et al., 2002; Bissett, 2002; Bajekal, 2005; ONS, 2006; Rasulo et al., 2007; Olatunde et al., 2010; Smith et al., 2010a,b; White and Edgar, 2010). However, there has been a lack of consistent and timely measurement of these metrics between census years.

The calculation of HEs such as DFLE and healthy life expectancy (HLE) (that is, the length of time an individual can expect to live in very good or good health) at sub-national level requires survey data with substantial sample sizes and un-clustered designs. For this reason, sub-national health expectancies have largely relied upon census data or aggregated data from other survey sources. However, due to the length of the aggregate period or the timeliness of the data, such estimates have a limited value in monitoring the $\mathrm{HE}$ of a given population.

Here we explore the potential of the ONS APS (see Box 1) to produce estimates of DFLE for men and women over the period 2006-08; firstly at the national level and then by increasingly detailed scales of analysis in England including clusters of area deprivation, regions and LAs. Analyses will focus on the viability of the APS as a source to monitor change over time and against national and regional means.

To validate this approach, we firstly present a comparison of estimates of limiting long-standing illness and DFLE at national level derived from the APS with estimates derived from the GLF and CHS. These latter surveys currently form the basis of ONS national health expectancies but are too small to be used in the calculation of health expectancies at sub-national levels except when aggregated over relatively long periods. 


\section{Methods}

In the first instance, the prevalence of self-reported limiting long-standing illness or disability among men and women in the UK and constituent countries for the period 2006-08 using the GLF/CHS was compared with figures derived from the APS over the same period. Only adults (aged 16 years and above) are included in this analysis as the APS does not collect data from children aged less than 16 years. Data derived from the GLF/CHS are not directly comparable with data derived from the APS due to differences in survey questions, survey design and weighting. Nevertheless, the GLF/CHS estimates provide important benchmarks with which to cross-validate estimates of disability obtained from the APS when evaluating the usefulness of this data source in constructing indicators of disability in the adult population. Further information about the survey sources is provided in Box 1.

The APS data were then used in the estimation of DFLE for men and women in England by clusters of Lower Super Output Areas (LSOAs) based on their Index of Multiple Deprivation (IMD) 2007 ranking, by English region and by English LA district level geographies. LA districts include unitary authorities, London boroughs, metropolitan districts and non-metropolitan districts in England. The Isles of Scilly and City of London were excluded from the analysis due to small sample sizes. Further information about LSOAs and the IMD 2007 is provided in Box 4.

Prevalence data from each survey source were combined with mortality data and mid-year population estimates (MYPE) over the analysis period to calculate estimates of DFLE at age 16 and at age 65 for men and women. Slope and Relative indices of inequality (SII and RII respectively) (see Box 5), were used to assess the absolute and relative inequality in LE and DFLE between clusters of deprivation. Boxes 1, 2, 3, 4 and 5 provide brief descriptions of the survey data and methods used in this analysis. 


\section{Box 1 Survey data}

\section{APS}

The APS is a continuous quarterly survey of private households in the UK, NHS housing and students in halls of residence (who are included at their home address). The survey consists of waves 1 and 5 of the Labour Force Survey (LFS) and additional boost cases for England, Wales and Scotland (Ashton and Kent, 2008). For this analysis non-overlapping survey data for the period 2006-08 were selected from the APS, namely waves 1 and 4 of the APS boost cases in each year and wave 5 of the LFS in 2006, waves 1 and 5 of the LFS in 2007 and wave 1 of the LFS in 2008. Survey data were re-weighted by ONS to reflect this recombination and differ from weights in the original APS/LFS datasets. The resulting aggregated dataset consisted of more than 475,000 respondents aged 16 years and above. The APS does not include data relating to children aged less than 16 years.

It should be noted that the APS and LFS combined dataset comprises a mix of face-to-face (wave 1) and telephone interviews (waves 4 and 5). This may result in mode effects, where responses vary on the basis of interview method adopted. There may also be issues with attrition bias for respondents in waves 4 and 5 of the survey, who are repeat respondents to the survey. It is beyond the scope of this study to evaluate the likely effect of these differences and any potential bias that may arise.

For analyses below national level, each survey's individual record was mapped to appropriate geographical boundaries using the Royal Mail Postcode Address File.

\section{GLF and CHS}

The GLF is an annual longitudinal survey of private households in England, Wales and Scotland. This survey has a rotating panel design and, in each year, around a third of the total sample is made up of new entrants (wave 1). The data from these new entrants are treated as cross-sectional and are used in the calculation of national HE estimates. The CHS is an annual cross-sectional survey of private households in Northern Ireland. Data from the CHS are combined with cross-sectional data from the GLF to calculate UK HE estimates. In the period 2006-08 this aggregated dataset consisted of more than 28,000 respondents aged 16 years and above. National estimates of HE at birth and at age 65 in the UK (ONS, 2010) also include estimates of the health of residents of medical and care communal establishments. The analyses in this report do not include this population and so will not match published estimates of DFLE at age 65 (ONS, 2010). 


\section{Box 2 Limiting long-standing illness or disability}

\section{APS}

Respondents to the APS were considered to have a limiting long-standing illness or disability if they responded 'Yes' to the following two questions:

Do you have any health problems or disabilities that you expect will last for a year or more?

Yes/No

If 'Yes' the respondent is then asked;

Do these health problems or disabilities, when taken singly or together, substantially limit your ability to carry out normal day to day activities? If you are receiving medication or treatment, please consider what the situation would be without the medication or treatment.

Yes/No

The questions asked in this data source are based on a number of criteria included in the Disability Discrimination Act, 1995 and 2005

\section{GLF/CHS}

Respondents to the GLF/CHS were considered to have a limiting long-standing illness or disability if they responded 'Yes' to the following questions:

Do you have any long-standing illness, disability or infirmity - by long-standing I mean anything that has troubled you over a period of time or that is likely to affect you over a period of time?

Yes/No

If 'Yes' the respondent is then asked;

Does this illness or disability (Do any of these illnesses or disabilities) limit your activities in any way?

Yes/No 


\section{Box 3 Disability-free life expectancy (DFLE)}

DFLE divides LE into estimated periods of life spent with and without a limiting long-standing illness or disability. This metric is calculated using the Sullivan period life table method which combines the prevalence of limiting long-standing illness or disability (see Box 2) with mortality data and MYPEs (Sullivan, 1971; Jagger, 1996). For these analyses, all data were aggregated over the three-year period 2006-08. MYPEs were adjusted to match the private household population by subtracting numbers resident in communal establishments; however, the mortality data used represent the entire population of adults aged 16 years and above.

Exclusion of the communal establishment population from survey data and MYPEs will tend to underestimate the prevalence of disability in the population and therefore lead to a slight skew in the analysis, particularly if there are large differences in the size of communal establishment populations across areas or clusters of deprivation. However, it is considered unlikely that the inclusion of communal establishment deaths in the mortality data materially alters the main findings of this study.

Estimates of DFLE differ in statistical precision depending on survey sample size, such that those with relatively large samples are more precise than those with smaller samples. This issue is particularly important for LA estimates. Estimates of LE and DFLE for men and women aged 65 are not presented by LA due to the high level of statistical imprecision. 


\section{Box 4 Area deprivation}

The IMD 2007 combines seven distinct domains of data to produce a single measure of relative deprivation for each LSOA in England. Similar measures have also been constructed for Wales, Northern Ireland and Scotland (Noble et al., 2001, 2003; National Assembly for Wales, 2005) although these are not comparable across countries. For this study, analyses by IMD 2007 are restricted to England. LSOAs are relatively similar in terms of population size and structure; each has approximately 1,500 residents. The 32,482 LSOAs in England can be ranked according to their IMD 2007 scores and grouped for subsequent analyses. Such groupings represent a continuum of relative deprivation: they are discrete groupings of areas, with a significant extent of difference within them.

The IMD has been criticised as conceptually problematic when used in health-related studies as it includes health as one of its deprivation domains (Morgan and Baker, 2006). Therefore, measurements of health using the IMD to group different areas may potentially suffer from mathematical-coupling where the integral health domain of the IMD biases the relationship with the health outcome under investigation. Recent studies however, have found little evidence to support this effect, concluding that the presence or absence of the health domain in the IMD has little or no effect in biasing the relationship between health and deprivation, particularly with regard to general health, limiting persistent illness and/or mortality as outcome measures (Adams and White, 2006; Gartner et al., 2008). 


\section{Box $5 \quad$ Slope and Relative indices of inequality}

To calculate the slope and relative index of inequality:

The quintiles were ordered by decreasing area deprivation, that is, from the most to the least deprived. The fraction of the total population in each quintile $(f)$ was calculated. The cumulative frequency $\left(c_{i}\right)$, that is the cumulative fraction of the population in successively less deprived quintiles, was also obtained and the relative deprivation rank $(x)$ for each quintile was calculated as:

$$
x=c_{i-1}+(0.5 \times f)
$$

The SII (slope of the regression line) was then estimated by regressing DFLE for each quintile against the relative deprivation rank $(\mathrm{x})$, weighted by the population in each quintile. SII can be interpreted as the difference in DFLE between the least and most deprived areas, taking into account deprivation across all areas.

The RII was calculated using the method described by Mackenbach and Kunst (1997). First, the predicted value of DFLE (ŷ) for the least deprived quintile, taking into account its relative deprivation rank, was estimated using a linear regression model. The SII was then divided by the predicted DFLE value, (SII / Ŷ). The result obtained represents the ratio of the DFLE of the most deprived areas to that of the least deprived. This was then expressed as a relative ratio by adding 1 to it, giving the modified RII.

$$
\text { Modified RII = 1+ (SII / ŷ ) }
$$

\section{Results}

All data are available online at www.statistics.gov.uk/hsq/downloads/hsq50art2.xls. Data are presented according to scale of analysis, such that national figures, including the comparison between survey sources, are presented first, followed by clusters of area deprivation, region and finally LA.

\section{Country comparisons by sex and survey source}

\section{Prevalence of limiting long-standing illness or disability}

The prevalence of LLSI was broadly consistent for men and women in the UK and constituent countries in each source (see Table 1). 


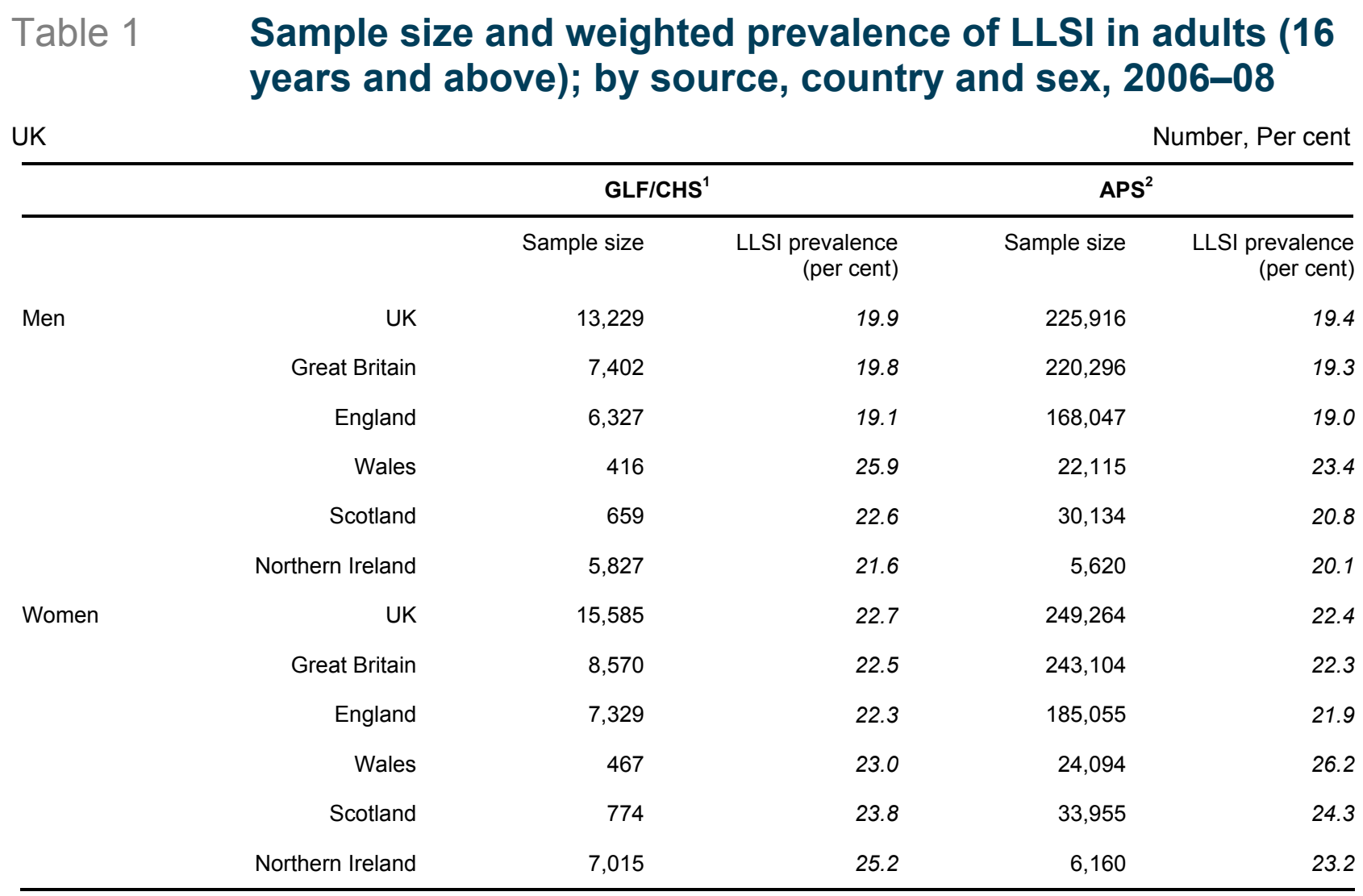

1 Great Britain based on cross-sectional component of GLF; Northern Ireland derived from the CHS; excludes residents of communal establishments

2 Excludes residents of communal establishments except NHS housing and students in halls of residence where inclusion takes place at their parents address

Source: ONS

For men APS prevalence estimates of LLSI were lower than those derived from the GLF/CHS. Differences ranged from just 0.1 per cent for England to 2.5 per cent for Wales; however, the direction of these differences was consistent between sources.

For women, there was no consistent pattern by source; the prevalence of LLSI in the APS was lower in the UK, Great Britain, England and Northern Ireland; but was higher for Wales and Scotland. Differences ranged from 0.2 per cent for Great Britain to 3.2 per cent for Wales.

\section{Disability-free life expectancy}

Estimates of DFLE at age 16 and at age 65 for men and women derived from APS prevalence data were lower in the UK, Great Britain, England, Wales and Scotland than those from the GLF/CHS. However, for Northern Ireland, DFLE for both sexes at age 16 were lower using CHS prevalence data, and for females at age 65, DFLEs based on CHS and APS data were equivalent (see Tables 2 and 3 ).

For men, DFLE at ages 16 and 65 were significantly lower in the UK, Great Britain and England using APS data compared with estimates based on GLF/CHS data. Differences observed between sources were not significant for Wales, Scotland or Northern Ireland (see Table 2). 


\section{Table 2 LE and DFLE for men at age 16 and at age 65; by survey source and country; 2006-08}

\begin{tabular}{|c|c|c|c|c|c|c|c|}
\hline \multirow[t]{3}{*}{ UK } & \multirow[b]{3}{*}{ LE } & \multirow{2}{*}{\multicolumn{3}{|c|}{ GLF/CHS $^{1}$}} & \multirow{2}{*}{\multicolumn{3}{|c|}{ APS $^{2}$}} \\
\hline & & & & & & & \\
\hline & & DFLE & $\begin{array}{r}\text { Lower } 95 \\
\text { per cent } \\
\text { confidence } \\
\text { interval }\end{array}$ & $\begin{array}{r}\text { Upper } 95 \\
\text { per cent } \\
\text { confidence } \\
\text { interval }\end{array}$ & DFLE & $\begin{array}{r}\text { Lower } 95 \\
\text { per cent } \\
\text { confidence } \\
\text { interval }\end{array}$ & $\begin{array}{r}\text { Upper } 95 \\
\text { per cent } \\
\text { confidence } \\
\text { interval }\end{array}$ \\
\hline \multicolumn{8}{|l|}{ Age 16} \\
\hline $\mathrm{UK}^{3}$ & 62.0 & 49.1 & 48.7 & 49.5 & 48.3 & 48.2 & 48.4 \\
\hline Great Britain $^{3}$ & 62.0 & 49.3 & 48.8 & 49.9 & 48.4 & 48.2 & 48.5 \\
\hline England $^{3}$ & 62.3 & 49.8 & 49.2 & 50.4 & 48.8 & 48.7 & 48.9 \\
\hline Wales & 61.4 & 46.4 & 44.0 & 48.9 & 45.3 & 45.0 & 45.7 \\
\hline Scotland & 59.5 & 46.5 & 44.8 & 48.2 & 45.6 & 45.3 & 45.9 \\
\hline Northern Ireland & 61.0 & 46.6 & 46.0 & 47.2 & 46.9 & 46.2 & 47.5 \\
\hline \multicolumn{8}{|l|}{ Age 65} \\
\hline $\mathrm{UK}^{3}$ & 17.4 & 10.5 & 10.2 & 10.8 & 9.7 & 9.6 & 9.8 \\
\hline Great Britain $^{3}$ & 17.4 & 10.6 & 10.2 & 11.0 & 9.7 & 9.6 & 9.8 \\
\hline England $^{3}$ & 17.5 & 10.8 & 10.3 & 11.2 & 9.9 & 9.8 & 10.0 \\
\hline Wales & 17.1 & 9.4 & 7.8 & 11.1 & 8.3 & 8.0 & 8.6 \\
\hline Scotland & 16.2 & 9.6 & 8.4 & 10.9 & 8.3 & 8.0 & 8.5 \\
\hline Northern Ireland & 16.8 & 9.1 & 8.6 & 9.6 & 9.3 & 8.8 & 9.9 \\
\hline
\end{tabular}

1 Great Britain based on cross-sectional component of GLF; Northern Ireland derived from the CHS; excludes residents of communal establishments

2 Excludes residents of communal establishments except NHS housing and students in halls of residence where inclusion takes place at their parents address

3 Significant differences in DFLE between GLF/CHS and APS

Source: ONS

Although small differences in DFLE at age 16 for men were detected using each source's prevalence data, the pattern by country was similar. Table 2 shows that DFLE was highest in England and lowest in Wales; the difference in DFLE was smallest for Northern Ireland (0.3 years) and greatest for Wales (1.1 years).

At age 65, DFLE for men was also highest in England for both data sources; however, the lowest estimate based on the CHS was in Northern Ireland and based on the APS was in Scotland and Wales. The difference in DFLE for each country by source was smallest for Northern Ireland $(0.3$ years) and greatest for Scotland (1.4 years).

For women, DFLE at age 16 based on the APS was significantly lower in the UK, Great Britain and Wales compared with that based on the GLF/CHS; at age 65 the same pattern was present in the UK, England, Wales and Scotland. Differences in DFLE between sources were not significant for Northern Ireland at both ages analysed (see Table 3). 


\section{Table 3 LE and DFLE for women at age 16 and at age 65; by survey source and country; 2006-08}

\begin{tabular}{|c|c|c|c|c|c|c|c|}
\hline \multirow[t]{3}{*}{ UK } & \multirow[b]{3}{*}{ LE } & \multirow{2}{*}{\multicolumn{3}{|c|}{ GLF/CHS ${ }^{1}$}} & \multirow{2}{*}{\multicolumn{3}{|c|}{ APS $^{2}$}} \\
\hline & & & & & & & \\
\hline & & DFLE & $\begin{array}{r}\text { Lower } 95 \\
\text { per cent } \\
\text { confidence } \\
\text { interval }\end{array}$ & $\begin{array}{r}\text { Upper } 95 \\
\text { per cent } \\
\text { confidence } \\
\text { interval }\end{array}$ & DFLE & $\begin{array}{r}\text { Lower } 95 \\
\text { per cent } \\
\text { confidence } \\
\text { interval }\end{array}$ & $\begin{array}{r}\text { Upper } 95 \\
\text { per cent } \\
\text { confidence } \\
\text { interval }\end{array}$ \\
\hline \multicolumn{8}{|l|}{ Age 16} \\
\hline$U^{3}$ & 66.1 & 50.1 & 49.7 & 50.6 & 49.3 & 49.2 & 49.4 \\
\hline Great Britain $^{3}$ & 66.2 & 50.4 & 49.7 & 51.0 & 49.3 & 49.2 & 49.5 \\
\hline England & 66.4 & 50.5 & 49.9 & 51.2 & 49.8 & 49.7 & 49.9 \\
\hline Wales $^{3}$ & 65.7 & 50.5 & 48.0 & 53.1 & 46.1 & 45.7 & 46.4 \\
\hline Scotland & 64.3 & 48.7 & 46.8 & 50.6 & 46.8 & 46.5 & 47.2 \\
\hline Northern Ireland & 65.7 & 47.5 & 46.9 & 48.2 & 48.1 & 47.4 & 48.8 \\
\hline \multicolumn{8}{|l|}{ Age 65} \\
\hline $\mathrm{UK}^{3}$ & 20.0 & 11.3 & 10.9 & 11.6 & 10.3 & 10.2 & 10.4 \\
\hline Great Britain $^{3}$ & 20.0 & 11.4 & 10.9 & 11.8 & 10.3 & 10.2 & 10.4 \\
\hline England $^{3}$ & 20.2 & 11.4 & 10.8 & 11.9 & 10.5 & 10.4 & 10.7 \\
\hline Wales $^{3}$ & 19.8 & 11.8 & 10.1 & 13.6 & 8.8 & 8.5 & 9.1 \\
\hline Scotland $^{3}$ & 18.8 & 11.2 & 9.9 & 12.6 & 9.1 & 8.8 & 9.3 \\
\hline Northern Ireland & 19.8 & 9.8 & 9.3 & 10.4 & 9.8 & 9.3 & 10.4 \\
\hline
\end{tabular}

1 Great Britain based on cross-sectional component of GLF; Northern Ireland derived from the CHS; excludes residents of communal establishments

2 Excludes residents of communal establishments except NHS housing and students in halls of residence where inclusion takes place at their parents address

3 Significant differences in DFLE between GLF/CHS and APS

Source: ONS

For women, DFLE at age 16 was highest in England for both data sources. The lowest DFLE, however, differed by source: Northern Ireland based on the CHS and Wales based on the APS.

The difference in the DFLE for each country by source was smallest for Northern Ireland ( 0.6 years) and greatest for Wales (4.5 years).

At age 65, the highest DFLE for women varied by data source: Wales based on the GLF and England based on the APS. The lowest DFLE also varied by source: Northern Ireland based on the CHS and Wales based on the APS. The difference in DFLE for each country by source was greatest for Wales (3.0 years); in Northern Ireland no difference was present. 


\section{Limiting long-standing illness or disability, life expectancy and disability-free life expectancy by area deprivation; England, 2006-08}

\section{Prevalence of limiting long-standing-illness}

There was a largely even distribution of respondents in the APS England sample across quintiles of deprivation, ranging from 19.3 to 21.2 per cent of the population in each area cluster (see Table 4).

\section{Table $4 \quad$ Prevalence of limiting long-standing illness in England ${ }^{1,2}$ : by area deprivation quintile, 2006-08}

England

\begin{tabular}{|c|c|c|c|c|c|c|}
\hline & Deprivation quintile & Persons & $\begin{array}{r}\text { Per cent } \\
\text { by area }\end{array}$ & $\begin{array}{r}\text { LLSI } \\
\text { Prevalence } \\
\text { (per cent) }\end{array}$ & $\begin{array}{r}\text { Lower } \\
95 \text { per cent } \\
\text { confidence } \\
\text { interval }\end{array}$ & $\begin{array}{r}\text { Upper } \\
95 \text { per cent } \\
\text { confidence } \\
\text { interval }\end{array}$ \\
\hline \multirow[t]{5}{*}{ Men } & 1 - least deprived & 33,345 & 19.8 & 15.1 & 15.0 & 15.1 \\
\hline & 2 & 33,714 & 20.1 & 16.7 & 16.7 & 16.8 \\
\hline & 3 & 33,690 & 20.0 & 18.0 & 18.0 & 18.0 \\
\hline & 4 & 33,331 & 19.8 & 20.7 & 20.6 & 20.7 \\
\hline & 5 - Most deprived & 33,966 & 20.2 & 25.1 & 25.1 & 25.2 \\
\hline \multicolumn{2}{|c|}{ Total/Ratio (5/1) } & 168,046 & .. & 1.7 & 1.6 & 1.7 \\
\hline \multirow[t]{5}{*}{ Women } & 1 - least deprived & 35,716 & 19.3 & 17.7 & 17.6 & 17.7 \\
\hline & 2 & 36,603 & 19.8 & 19.7 & 19.7 & 19.7 \\
\hline & 3 & 36,431 & 19.7 & 21.1 & 21.1 & 21.2 \\
\hline & 4 & 37,077 & 20.0 & 23.9 & 23.9 & 23.9 \\
\hline & 5 - Most deprived & 39,228 & 21.2 & 27.7 & 27.7 & 27.8 \\
\hline \multicolumn{2}{|c|}{ Total/Ratio (5/1) } & 185,055 & .. & 1.6 & 1.5 & 1.6 \\
\hline
\end{tabular}

1 Excludes residents of communal establishments except NHS housing and students in halls of residence where inclusion takes place at their parents address

2 Estimates of LLSI in each quintile are based upon weighted survey data taking into account both non-response and the age structure and sex of survey respondents. Data are not age-standardised.

3 Does not match England total for males in Table 1 due to missing location data for a single individual

Source: ONS

Table 4 shows that the prevalence of LLSI increased significantly for both men and women with increasing deprivation. Notably there was a 10 percentage point higher prevalence of LLSI in the most compared with the least deprived areas.

For men in the least deprived areas, 15.1 per cent reported an LLSI. In the most deprived areas this figure was 25.1 per cent. Men in these areas were therefore 70 per cent more likely to report an LLSI than their counterparts in the least deprived areas.

For women, the prevalence of LLSI was significantly greater in each quintile than for men. In the least deprived areas, 17.7 per cent of women reported an LLSI rising to 27.7 per cent in the most 
deprived areas. Women in the most deprived areas were therefore 60 per cent more likely to report an LLSI.

\section{DFLE by area deprivation}

In 2006-08, people living in the least deprived areas in England could expect significantly longer LE and DFLE than their counterparts in more deprived areas. Thus people in the least deprived areas spend a significantly greater proportion of their significantly longer lives free from a disability compared with those in the most deprived areas. DFLE for men and women at ages 16 and 65 fell significantly with each successive increase in relative deprivation (see Figures 1 to 4 ). It is notable that the inequality in DFLE across areas was substantially greater than the inequality in LE.

\section{Men at age 16}

At age 16, men living in the least deprived areas could expect to spend a further 54.0 years free from a disability; 13.2 years more their counterparts living in the most deprived areas who could expect a further 40.8 years free from disability (see Figure 1).

\section{Figure 1 LE and DFLE for men at age $16^{1}$ : by IMD 2007 quintile, 2006- 08}

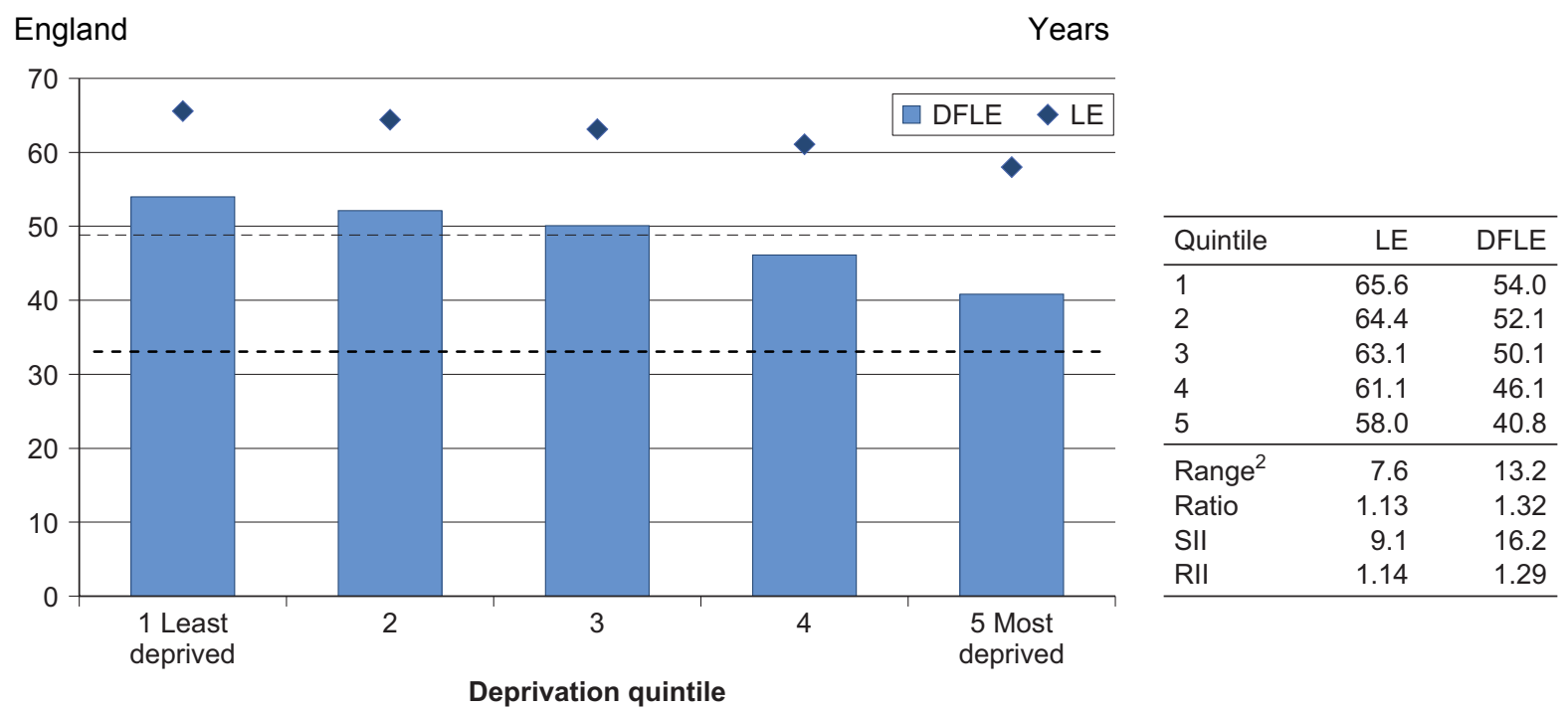

1 Excludes residents of communal establishments except NHS housing and students in halls of residence where inclusion takes place at their parents address

2 Estimates are rounded and may therefore not match the apparent difference in rounded estimates for quintiles 1 and 5

---- England DFLE average

Source: ONS

DFLE at age 16 was 32 per cent higher for men in the least deprived areas compared with those in the most deprived areas. The absolute difference in DFLE between quintile extremes taking into account deprivation across all quintiles, as measured by the SII, was 16.2 years and the relative inequality as measured by the modified RII was 1.29 . 
As a proportion of LE, those in the least deprived areas could expect to spend on average approximately 82 per cent of their remaining lives free from disability compared with only 70 per cent for those in the most deprived areas.

DFLE in the least deprived areas was 5.2 years higher and in the most deprived areas 8 years lower than the England average of 48.8 years.

\section{Men at age 65}

At age 65, men living in the least deprived areas could expect to spend 12.0 years of their remaining lives free from disability; 5.2 years more than their counterparts living in the most deprived areas who could expect to spend a further 6.9 years free from disability (see Figure 2).

\section{Figure 2 LE and DFLE for men at age $65^{1}$ : by IMD 2007 quintile, 2006- 08}

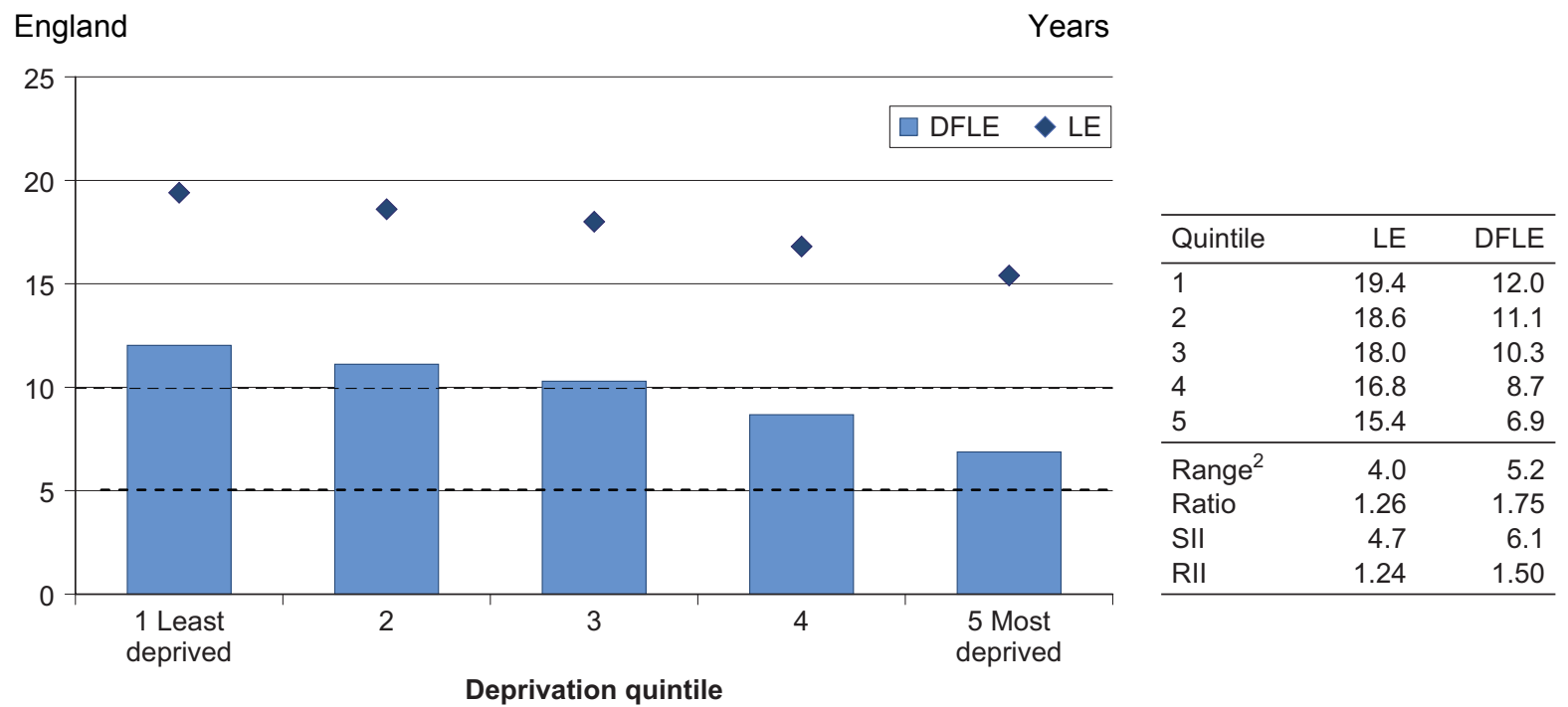

1 Excludes residents of communal establishments except NHS housing and students in halls of residence where inclusion takes place at their parents address

2 Estimates are rounded and may therefore not match the apparent difference in rounded estimates for quintiles 1 and 5

---- England DFLE average

Source: ONS

DFLE for men aged 65 living in the least deprived areas was 74 per cent higher than for those in the most deprived areas. The absolute difference in DFLE between quintile extremes taking into account deprivation across all quintiles, as measured by the SII, was 6.1 years and the relative inequality as measured by the modified RII was 1.50 .

By age 65, the proportion of life spent without disability had reduced to 62 per cent for men in the least deprived areas and 45 per cent for their counterparts in the most deprived areas.

DFLE in the least deprived areas was 2.0 years higher and in the most deprived areas 3.0 years lower than the England average of 9.9 years. 


\section{Women at age 16}

At age 16, women living in the least deprived areas could expect to spend 54.6 years free from disability; 12.6 years more than their counterparts living in the most deprived areas who could expect to spend 42.0 years free from disability (see Figure 3 ).

\section{Figure 3 LE and DFLE for women at age 16 ${ }^{1}$ : by IMD 2007 quintile, 2006-08}

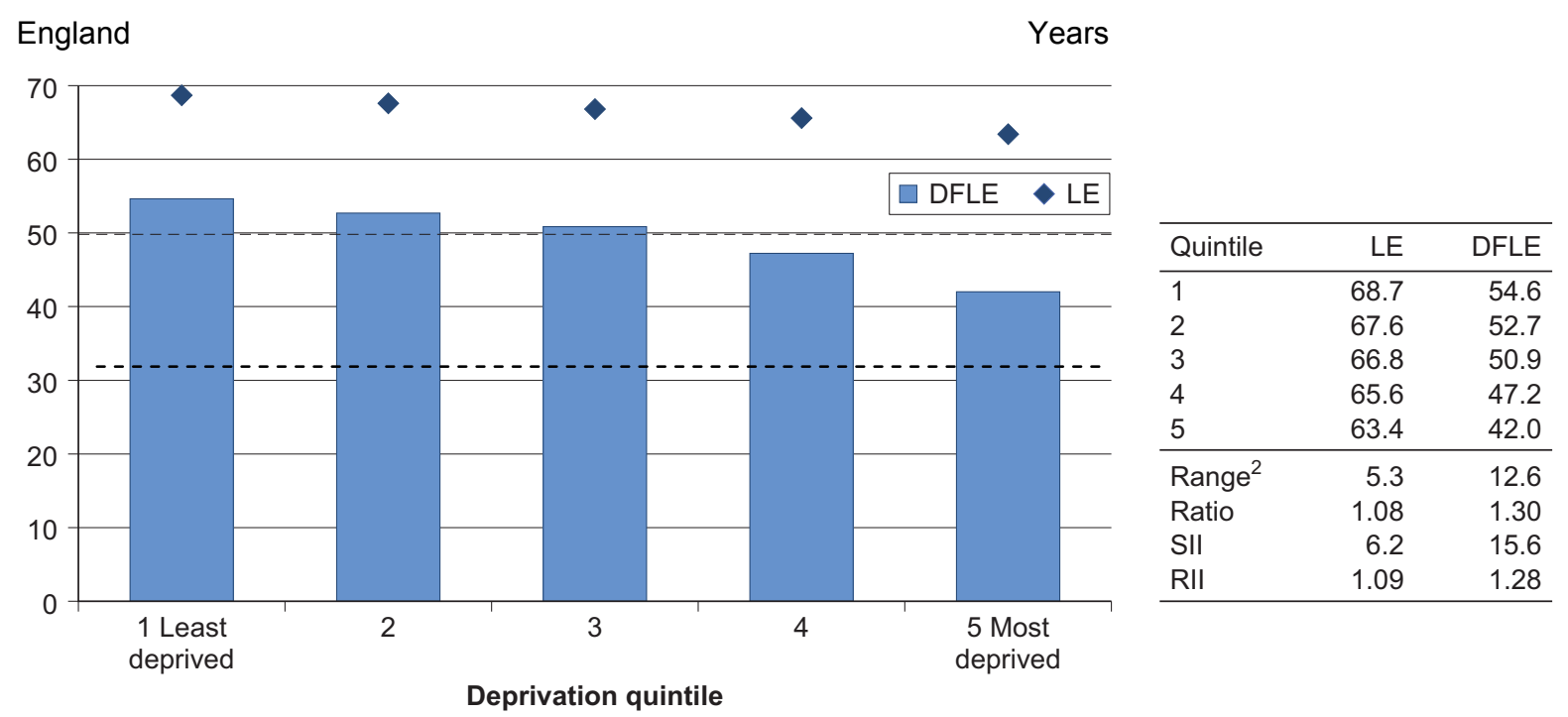

1 Excludes residents of communal establishments except NHS housing and students in halls of residence where inclusion takes place at their parents address

2 Estimates are rounded and may therefore not match the apparent difference in rounded estimates for quintiles 1 and 5

---- England DFLE average

Source: ONS

The DFLE of women aged 16 in the least deprived areas was 30 per cent higher than for those in the most deprived areas. The absolute difference in DFLE between quintile extremes taking into account deprivation across all quintiles, as measured by the SII, was 15.6 years and the relative inequality as measured by the modified RII was 1.28 .

In the least deprived areas women could expect to spend approximately 80 per cent of their remaining lives at age 16 without a disability compared with 66 per cent for those in the most deprived areas.

DFLE in the least deprived areas was 4.8 years higher and in the most deprived areas 7.8 years lower than the England average of 49.8 years. 


\section{Women at age 65}

At age 65, women living in the least deprived areas could expect to spend 12.6 years of their remaining lives free from disability; 5.0 years more than their counterparts in the most deprived areas who could expect to spend a further 7.5 years free from disability (see Figure 4).

DFLE for these women was 67 per cent higher in the least deprived areas than in the most deprived areas. The absolute difference in DFLE between quintile extremes taking into account deprivation across all quintiles, as measured by the SII, was 6.1 years and the relative inequality as measured by the modified RII was 1.47 .

In addition, the proportion of life these women could expect to spend without disability was approximately 58 per cent in the least deprived areas and only 40 per cent in the most deprived areas.

DFLE in the least deprived areas was 2.1 years higher and in the most deprived areas 3.0 years lower than the England average of 10.5 years.

\section{Figure 4 LE and DFLE for women at age $65^{1}$ : by IMD 2007 quintile, 2006-08}

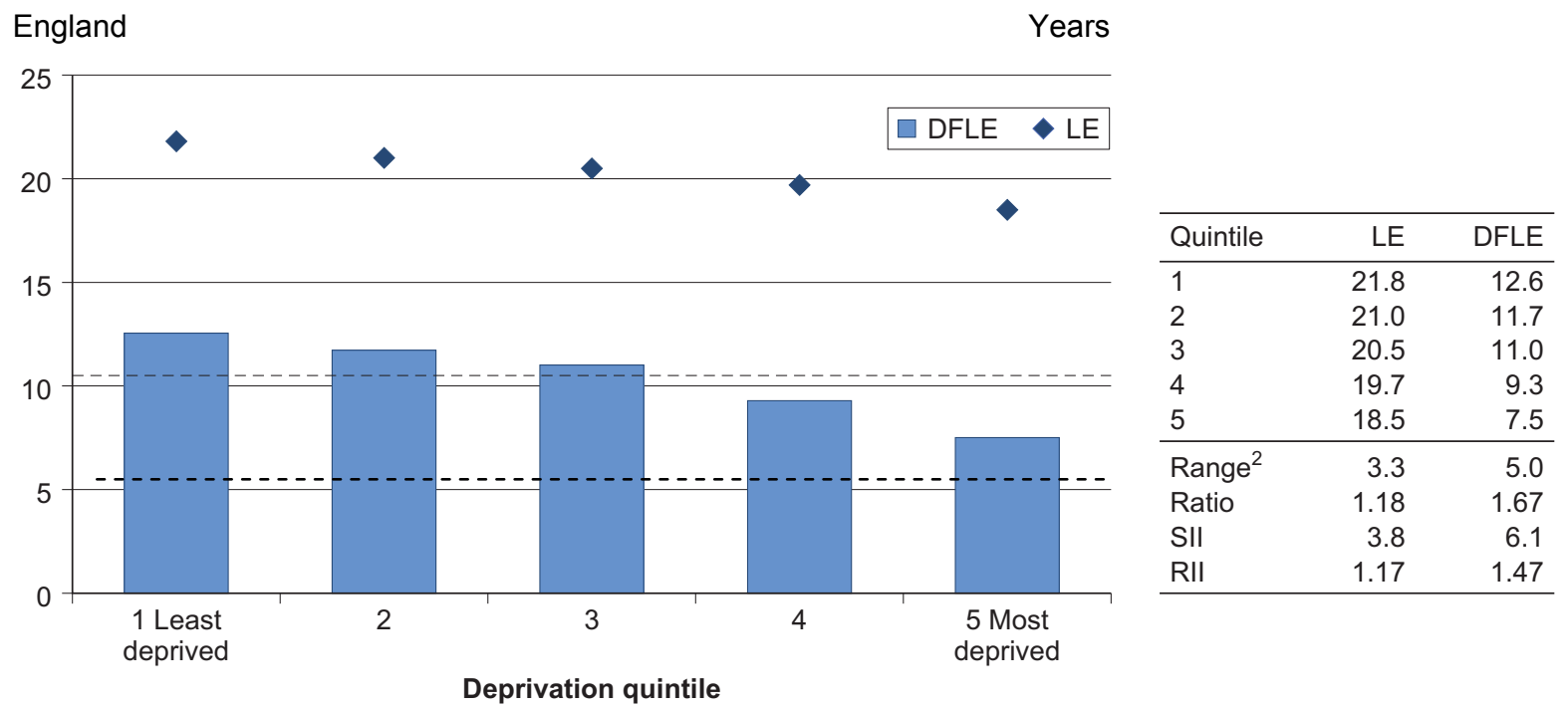

1 Excludes residents of communal establishments except NHS housing and students in halls of residence where inclusion takes place at their parents address

2 Estimates are rounded and may therefore not match the apparent difference in rounded estimates for quintiles 1 and 5

---- England DFLE average

Source: ONS 


\section{Life expectancy and disability-free life expectancy by English region, 2006-08}

LE and DFLE at age 16 and 65 for men and women varied significantly across the nine regions of England with a clear north-south divide (see Tables 5 to 9). DFLE at age 16 for both men and women was lowest in the North East and highest in the South East. LE predominantly followed this pattern in most cases. The results presented here are based on rankings of DFLE and do not reflect a similar ranking in LE.

\section{Men at age 16}

At age 16, men in the North East could expect to live, on average, a further 61.0 years; almost three-quarters (73 per cent, 44.2 years) of this time spent disability-free. By contrast, men's life expectancy at age 16 in the South East was 63.7 years, with more than 80 per cent (51.3 years) spent disability-free (see Table 5). The gap in DFLE between these regions was 2.5 times greater than the equivalent gap in LE.

Contrasts between the North East and North West regions are also noteworthy; despite having identical LE at 61.0 years, DFLE for men aged 16 in the North West was 2.6 years higher than for men in the North East.

\begin{tabular}{|c|c|c|c|c|c|}
\hline \multicolumn{5}{|l|}{ England } & Years, Per cent \\
\hline Region & LE & DFLE & $\begin{array}{r}\text { Lower } 95 \text { per } \\
\text { cent } \\
\text { confidence } \\
\text { interval }\end{array}$ & $\begin{array}{r}\text { Upper } 95 \text { per } \\
\text { cent } \\
\text { confidence } \\
\text { interval }\end{array}$ & $\begin{array}{l}\text { Percentage of life } \\
\text { disability-free }\end{array}$ \\
\hline North East & 61.0 & 44.2 & 43.8 & 44.7 & 72.6 \\
\hline North West & 61.0 & 46.8 & 46.5 & 47.1 & 76.8 \\
\hline Yorkshire and The Humber & 61.8 & 47.1 & 46.7 & 47.5 & 76.2 \\
\hline East Midlands & 62.4 & 48.1 & 47.7 & 48.6 & 77.1 \\
\hline West Midlands & 61.9 & 48.5 & 48.1 & 48.9 & 78.4 \\
\hline East of England & 63.5 & 50.7 & 50.3 & 51.1 & 79.9 \\
\hline London & 62.8 & 48.9 & 48.5 & 49.3 & 77.9 \\
\hline South East & 63.7 & 51.3 & 50.9 & 51.6 & 80.5 \\
\hline South West & 63.5 & 50.4 & 50.0 & 50.8 & 79.3 \\
\hline England & 62.3 & 48.8 & 48.7 & 48.9 & 78.3 \\
\hline Range (South East/North East) & 2.7 & 7.0 & 6.4 & 7.6 & .. \\
\hline
\end{tabular}

1 Excludes residents of communal establishments except NHS housing and students in halls of residence where inclusion takes place at their parents address

Source: ONS 


\section{Men at age 65}

Similar patterns in the ranking of LE and DFLE were apparent for men aged 65; both metrics were lowest in the North East and highest in the South East. In the North East, men could expect to live, on average, a further 16.7 years; but less than half of this time (47 per cent: 7.8 years) was spent disability-free. By contrast, men in the South East could expect to spend 61 per cent of their remaining lives disability-free (11.2 years out of 18.4 years) (see Table 6).

For men aged 65 the gap in DFLE between the North East and South East was 3.4 years; almost twice the gap in LE of 1.8 years. Hence while LE in the South East was 11 per cent higher than in the North East, DFLE was 44 per cent higher.

For men, the difference in the proportion of life spent without disability between the regions with the highest and lowest DFLE was greater at age 65 than at age 16; only 8 percentage points at age 16 and more than 14 percentage points at age 65

Table 6 LE and DFLE for men at age $65^{1}$ : by English region, 2006-08 England Years, Per cent

\begin{tabular}{|c|c|c|c|c|c|}
\hline Region & LE & DFLE & $\begin{array}{r}\text { Lower } 95 \text { per } \\
\text { cent } \\
\text { confidence } \\
\text { interval }\end{array}$ & $\begin{array}{r}\text { Upper } 95 \text { per } \\
\text { cent } \\
\text { confidence } \\
\text { interval }\end{array}$ & $\begin{array}{r}\text { Percentage of life } \\
\text { disability-free }\end{array}$ \\
\hline North East & 16.7 & 7.8 & 7.4 & 8.2 & 46.7 \\
\hline North West & 16.8 & 9.1 & 8.8 & 9.3 & 53.9 \\
\hline Yorkshire and The Humber & 17.2 & 9.0 & 8.7 & 9.3 & 52.0 \\
\hline East Midlands & 17.5 & 9.4 & 9.0 & 9.7 & 53.4 \\
\hline West Midlands & 17.4 & 9.8 & 9.5 & 10.1 & 56.5 \\
\hline East of England & 18.2 & 10.9 & 10.6 & 11.2 & 59.7 \\
\hline London & 18.1 & 9.8 & 9.5 & 10.2 & 54.3 \\
\hline South East & 18.4 & 11.2 & 11.0 & 11.5 & 60.9 \\
\hline South West & 18.4 & 11.0 & 10.7 & 11.3 & 59.6 \\
\hline England & 17.5 & 9.9 & 9.8 & 10.0 & 56.6 \\
\hline Range (South East/North East) & 1.8 & 3.4 & 3.0 & 3.9 & .. \\
\hline
\end{tabular}

1 Excludes residents of communal establishments except NHS housing and students in halls of residence where inclusion takes place at their parents address

Source: ONS 


\section{Women at age 16}

For women at age 16, LE and DFLE were not similarly ranked. Although both metrics were lowest in the North East, LE was highest in the South West while DFLE was highest in the South East.

Those in the North East could expect to live, on average, for a further 65.1 years, with less than three-quarters (69 per cent, 45.2 years) spent disability-free. By contrast, those in the South East had a LE of 67.4 years, expecting to spend 77 per cent (51.8 years) of it disability-free (see Table 7 ).

There was a gap of 2.3 years in LE between the South East and the North East but the gap in DFLE between them was almost three times greater at 6.6 years. As with men, although LE at age 16 for women in the North East and North West regions was almost identical, DFLE was 2.3 years higher in the North West than in the North East.

\section{Table 7 LE and DFLE for women at age $16^{1}$ : by English region, 2006-08}

England

Years, Per cent

\begin{tabular}{|c|c|c|c|c|c|}
\hline Region & LE & DFLE & $\begin{array}{r}\text { Lower } 95 \text { per } \\
\text { cent } \\
\text { confidence } \\
\text { interval }\end{array}$ & $\begin{array}{r}\text { Upper } 95 \text { per } \\
\text { cent } \\
\text { confidence } \\
\text { interval }\end{array}$ & $\begin{array}{l}\text { Percentage of life } \\
\text { disability-free }\end{array}$ \\
\hline North East & 65.1 & 45.2 & 44.7 & 45.7 & 69.4 \\
\hline North West & 65.1 & 47.5 & 47.1 & 47.8 & 72.9 \\
\hline Yorkshire and The Humber & 65.9 & 48.1 & 47.7 & 48.5 & 73.1 \\
\hline East Midlands & 66.3 & 49.4 & 48.9 & 49.8 & 74.4 \\
\hline West Midlands & 66.2 & 49.4 & 49.0 & 49.8 & 74.7 \\
\hline East of England & 67.2 & 51.5 & 51.1 & 52.0 & 76.7 \\
\hline London & 67.2 & 50.4 & 50.0 & 50.8 & 75.0 \\
\hline South East & 67.4 & 51.8 & 51.4 & 52.1 & 76.9 \\
\hline South West & 67.5 & 51.6 & 51.2 & 52.0 & 76.4 \\
\hline England & 66.4 & 49.8 & 49.7 & 49.9 & 75.0 \\
\hline Range (South East/North East) & 2.3 & 6.6 & 6.0 & 7.2 & \\
\hline
\end{tabular}

1 Excludes residents of communal establishments except NHS housing and students in halls of residence where inclusion takes place at their parents address

Source: ONS 


\section{Women aged 65}

Similar patterns in the ranking of LE and DFLE were apparent for women aged 65; lowest in the North East and highest in the South West. In the North East, women could expect to live for a further 19.2 years, with less than half (43 per cent; 8.3 years) spent disability-free. By contrast, women in the South West could expect to spend 56 per cent (11.9 years) of their remaining lives disability-free (see Table 8).

For women aged 65, the gap in DFLE between the North East and South West was 3.6 years; 75 per cent higher than that in LE; 2.0 years.

For women, the difference in the proportion of life spent without disability between the regions with the highest and lowest DFLE was greater at age 65 than at age 16; at age 16 almost 8 per cent and at age 65 more than 13 per cent.

\section{Table 8 LE and DFLE for women at age $65^{1}$ : by English region, 2006-08}

\begin{tabular}{|c|c|c|c|c|c|}
\hline \multicolumn{5}{|l|}{ England } & Years, Per cent \\
\hline Region & LE & DFLE & $\begin{array}{r}\text { Lower } 95 \text { per } \\
\text { cent } \\
\text { confidence } \\
\text { interval }\end{array}$ & $\begin{array}{r}\text { Upper } 95 \text { per } \\
\text { cent } \\
\text { confidence } \\
\text { interval }\end{array}$ & $\begin{array}{r}\text { Percentage of life } \\
\text { disability-free }\end{array}$ \\
\hline North East & 19.2 & 8.3 & 7.9 & 8.7 & 43.2 \\
\hline North West & 19.4 & 9.4 & 9.1 & 9.6 & 48.4 \\
\hline Yorkshire and The Humber & 19.8 & 9.8 & 9.5 & 10.1 & 49.5 \\
\hline East Midlands & 20.2 & 10.2 & 9.8 & 10.6 & 50.4 \\
\hline West Midlands & 20.1 & 10.6 & 10.2 & 10.9 & 52.5 \\
\hline East of England & 20.7 & 11.2 & 10.9 & 11.6 & 54.1 \\
\hline London & 20.9 & 10.8 & 10.4 & 11.1 & 51.5 \\
\hline South East & 21.0 & 11.5 & 11.3 & 11.8 & 55.0 \\
\hline South West & 21.2 & 11.9 & 11.6 & 12.2 & 56.3 \\
\hline England & 20.2 & 10.5 & 10.4 & 10.6 & 52.0 \\
\hline Range (South West/North East) & 1.9 & 3.6 & 3.1 & 4.1 & .. \\
\hline
\end{tabular}

1 Excludes residents of communal establishments except NHS housing and students in halls of residence where inclusion takes place at their parents address

Source: ONS 


\section{Life expectancy and disability-free life expectancy for men and women at age 16 by local authority district; England, 2006-08}

Data for the highest and lowest LAs in each region are presented consecutively. The local authority sample sizes available from APS survey data ranged from just 180 people in West Somerset to 4,242 people in Birmingham. At age 16 the precision of DFLE estimates for men and women ranged from 4 to 24 per cent around the point estimate; the mean was 11 per cent. At age 65 the equivalent range was 16 to 112 per cent; the mean was 42 per cent. For this reason this article does not present analyses at age 65, however, the accompanying Excel workbook contains all estimates of LE and DFLE and associated 95 per cent Cls at age 16 and 65 by sex. When analysed by fifths ranked according to DFLE, six LAs in the lowest fifth, representing just 2 per cent of all LAs, were not significantly different from the England average. For females this figure was slightly higher, with 10 LAs not significantly different from the England average, representing around 3 per cent of all LAs. At the other end of the scale, for males just one LA in the top fifth of LAs by DFLE was not significantly different from the England average, representing less than 1 per cent of all LAs. For females, this figure was again slightly higher with four LAs in the top fifth that were not significantly different from the England average, representing around 1 per cent of all LAs.

\section{Men at age 16}

LE varied by more than 10 years across the LAs, ranging from 58.3 years in Blackpool to 68.6 years in Kensington and Chelsea. The range in DFLE at age 16 was more than 15 years across LAs, ranging from 41.2 years in Barnsley to 56.8 years in Surrey Heath (see Figure 5).

Of the 324 LAs in the analysis, 65 LAs had DFLE estimates that were significantly lower than the England average of 48.8 years (95 per cent confidence interval $(\mathrm{Cl}), 48.7-48.9$ years). Of these, 59 were in the lowest fifth of LAs when ranked by DFLE, representing 91 per cent of this grouping. By contrast, 82 LAs had DFLE estimates that were significantly higher than the England average and 63 of these were placed in the highest fifth, representing 77 per cent of this grouping. 


\section{Figure 5 DFLE for men at age $16^{1}$ : by local authority district, 2006-08}

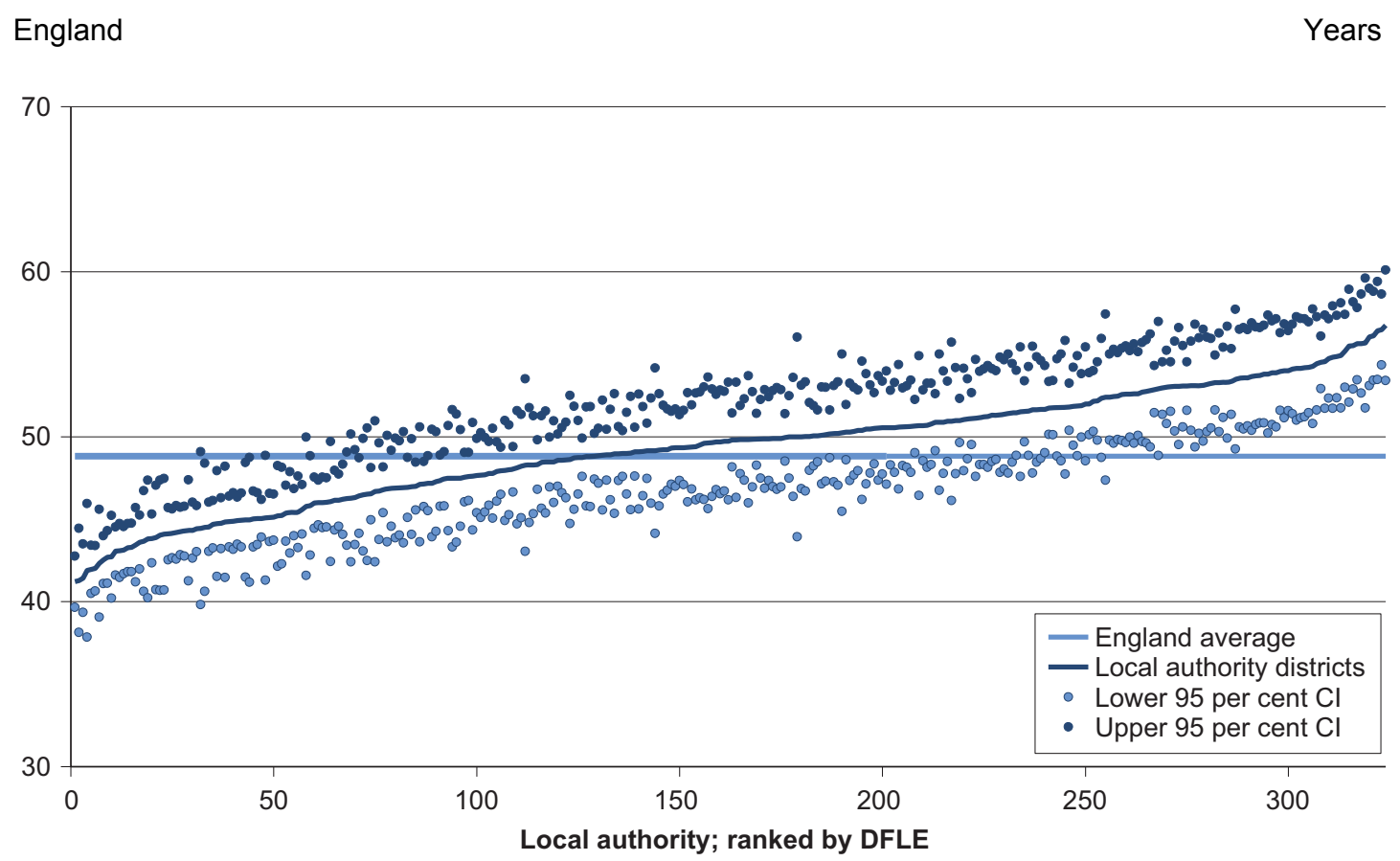

1 Excludes residents of communal establishments except NHS housing and students in halls of residence where inclusion takes place at their parents address

Source: ONS

Summary statistics for LAs by English region for men in 2006-08 are shown in Table 9 and Figures 6 and 7.

In the North East and North West, 83 per cent and 97 per cent of LAs respectively were in the bottom fifth of all LAs in England when ranked by DFLE. None of the LAs in the North East and only one (3 per cent) in the North West appeared in the top fifth in England. The North East had no LAs with DFLE estimates significantly higher than the England average; in the North West three (8 per cent) LAs were significantly higher.

By contrast, in the South East and South West just 6 per cent of LAs were in the lowest fifth in England when ranked by DFLE; 40 per cent and 25 per cent respectively were in the highest fifth. Six per cent of LAs in the South East and South West had estimates of DFLE that were significantly lower than the England average and 46 per cent and 31 per cent respectively had estimates of DFLE that were significantly higher than the England average. 


\section{Table 9 Summary statistics ${ }^{1}$ of DFLE for men aged 16: by local authority district, 2006-08}

England

\begin{tabular}{|c|c|c|c|c|c|c|}
\hline English Region & $\begin{array}{l}\text { Number in } \\
\text { lowest fifth of } \\
\text { LAs (per cent) }\end{array}$ & $\begin{array}{l}\text { Number in } \\
\text { highest fifth } \\
\text { of LAs (per } \\
\text { cent) }\end{array}$ & $\begin{array}{l}\text { Number } \\
\text { significantly } \\
\text { lower than } \\
\text { England } \\
\text { average (per } \\
\text { cent) }\end{array}$ & $\begin{array}{c}\text { Number } \\
\text { significantly } \\
\text { higher than } \\
\text { England } \\
\text { average (per } \\
\text { cent) }\end{array}$ & $\begin{array}{l}\text { LA with highest } \\
\text { DFLE, years (95 } \\
\text { per cent Cl) }\end{array}$ & $\begin{array}{l}\text { LA with lowest } \\
\text { DFLE, years (95 } \\
\text { per cent CI) }\end{array}$ \\
\hline North East & $10(83 \%)$ & 0 & $11(92 \%)$ & 0 & $\begin{array}{l}\text { Northumberland, } \\
48.0(46.6-49.4)\end{array}$ & $\begin{array}{r}\text { Sunderland, } \\
41.9(40.5-43.4)\end{array}$ \\
\hline North West & $38(97 \%)$ & $1(3 \%)$ & $28(72 \%)$ & $3(8 \%)$ & $\begin{array}{r}\text { Ribble Valley, } \\
54.3(50.8-57.7)\end{array}$ & $\begin{array}{r}\text { Hyndburn, } \\
42.3(39.1-45.6)\end{array}$ \\
\hline Yorkshire and The Humber & $6(29 \%)$ & $1(5 \%)$ & $8(38 \%)$ & $2(10 \%)$ & $\begin{array}{l}\text { Richmondshire, } \\
53.1 \text { (49.7-56.5) }\end{array}$ & $\begin{array}{r}\text { Barnsley, } \\
41.2(39.7-42.8)\end{array}$ \\
\hline East Midlands & $11(28 \%)$ & $4(10 \%)$ & $10(25 \%)$ & $4(10 \%)$ & $\begin{array}{r}\text { Rutland, } \\
54.2(51.2-57.2)\end{array}$ & $\begin{array}{r}\text { North West } \\
\text { Leicestershire, } \\
41.3(38.1-44.4)\end{array}$ \\
\hline West Midlands & $4(13 \%)$ & $6(20 \%)$ & $4(13 \%)$ & $8(27 \%)$ & $\begin{array}{r}\text { Lichfield, } \\
54.5(51.7-57.4)\end{array}$ & $\begin{array}{r}\text { Sandwell, } \\
44.4(43.0-45.8)\end{array}$ \\
\hline East of England & $4(9 \%)$ & $28(60 \%)$ & $4(9 \%)$ & $18(38 \%)$ & $\begin{array}{r}\text { Maldon, } \\
56.0(53.1-59.0)\end{array}$ & $\begin{array}{l}\text { Great Yarmouth, } \\
41.9(37.9-45.9)\end{array}$ \\
\hline London & $5(16 \%)$ & $2(6 \%)$ & $6(19 \%)$ & $4(13 \%)$ & $\begin{array}{r}\text { Kensington \& } \\
\text { Chelsea, } \\
53.5(49.2-57.7)\end{array}$ & $\begin{array}{r}\text { Newham, } \\
41.4(39.3-43.5)\end{array}$ \\
\hline South East & $4(6 \%)$ & $27(40 \%)$ & $4(6 \%)$ & $31(46 \%)$ & $\begin{array}{r}\text { Surrey Heath, } \\
56.8(53.4-60.1)\end{array}$ & $\begin{array}{r}\text { Eastbourne, } \\
43.8(40.2-47.4)\end{array}$ \\
\hline South West & $2(6 \%)$ & $9(25 \%)$ & $2(6 \%)$ & $11(31 \%)$ & $\begin{array}{r}\text { Stroud, } \\
56.5(54.3-58.6)\end{array}$ & $\begin{array}{r}\text { Plymouth, } \\
44.9(43.3-46.6)\end{array}$ \\
\hline
\end{tabular}

1 Percentages are rounded to the nearest whole number

Source: ONS 


\section{Figure 6 DFLE for men aged $16^{1}$ : by local authority district ${ }^{2,3}, 2006-08$}

England

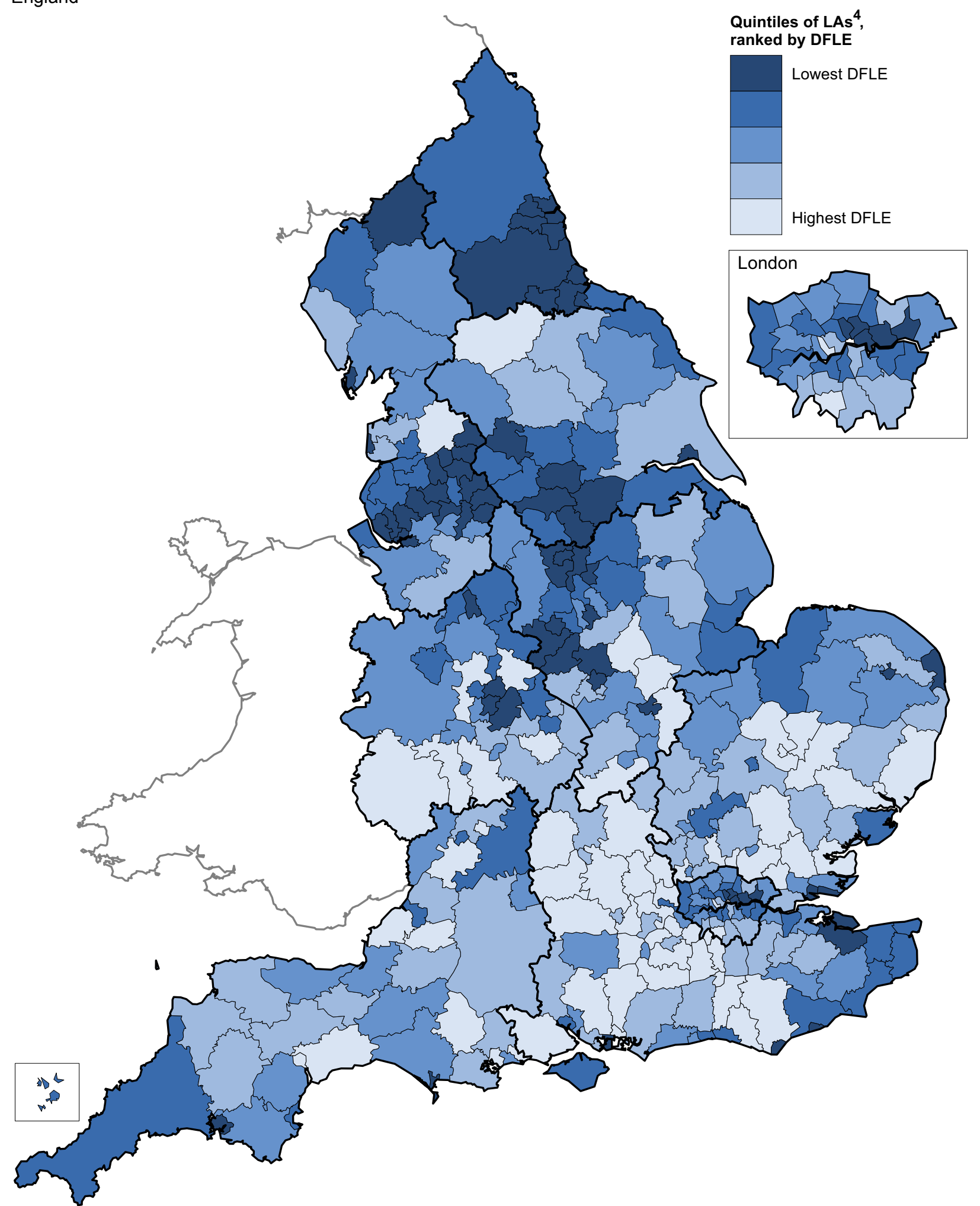

1 Excludes residents of communal establishments except NHS housing and

students in halls of residence where inclusion takes place at their parent's address.

2 After the April 2009 re-organisation.

3 Local authority districts include unitary authorities, London boroughs, metropolitan districts

and non-metropolitan districts in England. Excludes Isles of Scilly and City of London.

4 Each quintile comprises 65 LAs with the exception of the quintile with the highest

DFLE which has 64. 


\section{Figure 7 DFLE for men at age $16^{1}$ : by local authority district and English region, 2006-08}

England

Years

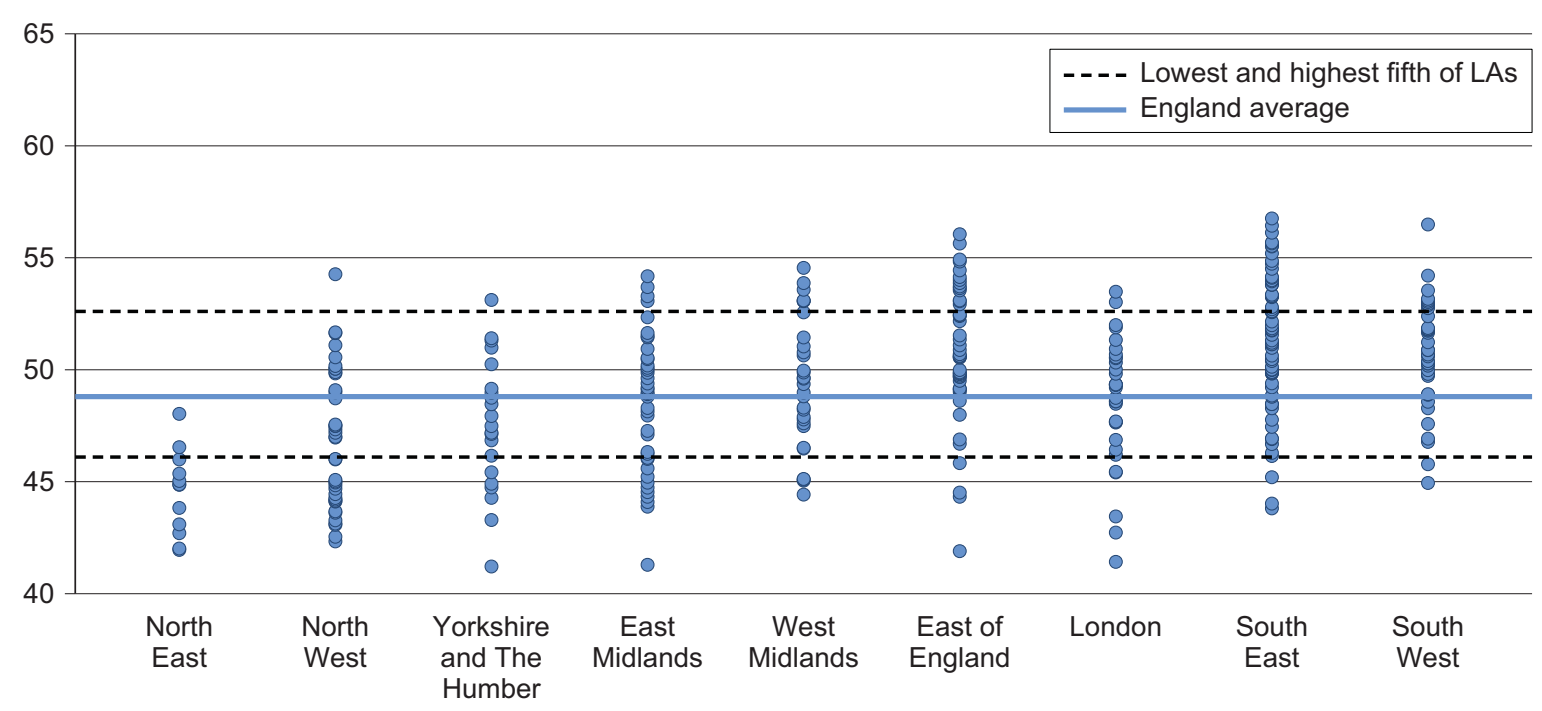

1 Excludes residents of communal establishments except NHS housing and students in halls of residence where inclusion takes place at their parents address

Source: ONS

The top and bottom ten LAs by DFLE at age 16 for men in England are shown in Table 10. The data for all LAs can be found in the associated datasets published on-line. 


\section{Table 10 LE and DFLE for men at age $16^{1}$ : bottom and top 10 local authority districts ranked by DFLE, 2006-08}

England

Years, Per cent

\begin{tabular}{|c|c|c|c|c|c|c|}
\hline Local Authority & Region & LE & DFLE & $\begin{array}{c}\text { Lower } 95 \text { per } \\
\text { cent confidence c } \\
\text { interval }\end{array}$ & $\begin{array}{c}\text { Upper } 95 \text { per } \\
\text { ent confidence } \\
\text { interval d }\end{array}$ & $\begin{array}{r}\begin{array}{r}\text { Percentage } \\
\text { of life } \\
\text { disability-free }\end{array}\end{array}$ \\
\hline Barnsley & Yorkshire and the Humber & 60.5 & 41.2 & 39.7 & 42.8 & 68.1 \\
\hline North West Leicestershire & East Midlands & 62.3 & 41.3 & 38.1 & 44.4 & 66.2 \\
\hline Newham & London & 60.2 & 41.4 & 39.3 & 43.5 & 68.8 \\
\hline Great Yarmouth & East of England & 61.7 & 41.9 & 37.9 & 45.9 & 67.9 \\
\hline Sunderland & North East & 60.0 & 41.9 & 40.5 & 43.4 & 69.9 \\
\hline County Durham & North East & 61.2 & 42.0 & 40.6 & 43.4 & 68.6 \\
\hline Hyndburn & North West & 60.0 & 42.3 & 39.1 & 45.6 & 70.5 \\
\hline Manchester & North West & 58.6 & 42.5 & 41.1 & 44.0 & 72.6 \\
\hline Gateshead & North East & 60.8 & 42.7 & 41.1 & 44.3 & 70.3 \\
\hline Tower Hamlets & London & 59.8 & 42.7 & 40.2 & 45.2 & 71.4 \\
\hline England & & 62.3 & 48.8 & 48.7 & 48.9 & 78.3 \\
\hline Runnymede & South East & 64.8 & 55.5 & 52.1 & 58.9 & 85.7 \\
\hline Waverley & South East & 65.2 & 55.5 & 52.9 & 58.2 & 85.1 \\
\hline Chelmsford & East of England & 64.9 & 55.6 & 53.4 & 57.8 & 85.8 \\
\hline Chiltern & South East & 64.6 & 55.6 & 52.6 & 58.6 & 86.1 \\
\hline Epsom and Ewell & South East & 65.4 & 55.7 & 51.7 & 59.6 & 85.2 \\
\hline Maldon & East of England & 63.2 & 56.0 & 53.1 & 59.0 & 88.7 \\
\hline Wycombe & South East & 64.9 & 56.1 & 53.4 & 58.8 & 86.4 \\
\hline Mole Valley & South East & 64.9 & 56.4 & 53.5 & 59.4 & 87.0 \\
\hline Stroud & South West & 63.4 & 56.5 & 54.3 & 58.6 & 89.1 \\
\hline Surrey Heath & South East & 64.4 & 56.8 & 53.4 & 60.1 & 88.1 \\
\hline Range (Surrey Health/Barnsley) & & 3.9 & 15.5 & 11.0 & 20.1 & .. \\
\hline
\end{tabular}

1 Excludes residents of communal establishments except NHS housing and students in halls of residence where inclusion takes place at their parents address

Source: ONS 


\section{Women at age 16}

Among women LE at age 16 varied by almost 10 years across the LAs, ranging from 63.3 years in Halton to 73.0 years in Kensington and Chelsea; however, the contrast in DFLE was more than 18 years, ranging from 41.7 years in Knowsley to 60.2 years in Tandridge (see Figure 8).

\section{Figure 8 DFLE for women at age $16^{1}$ : by local authority district, 2006-08}

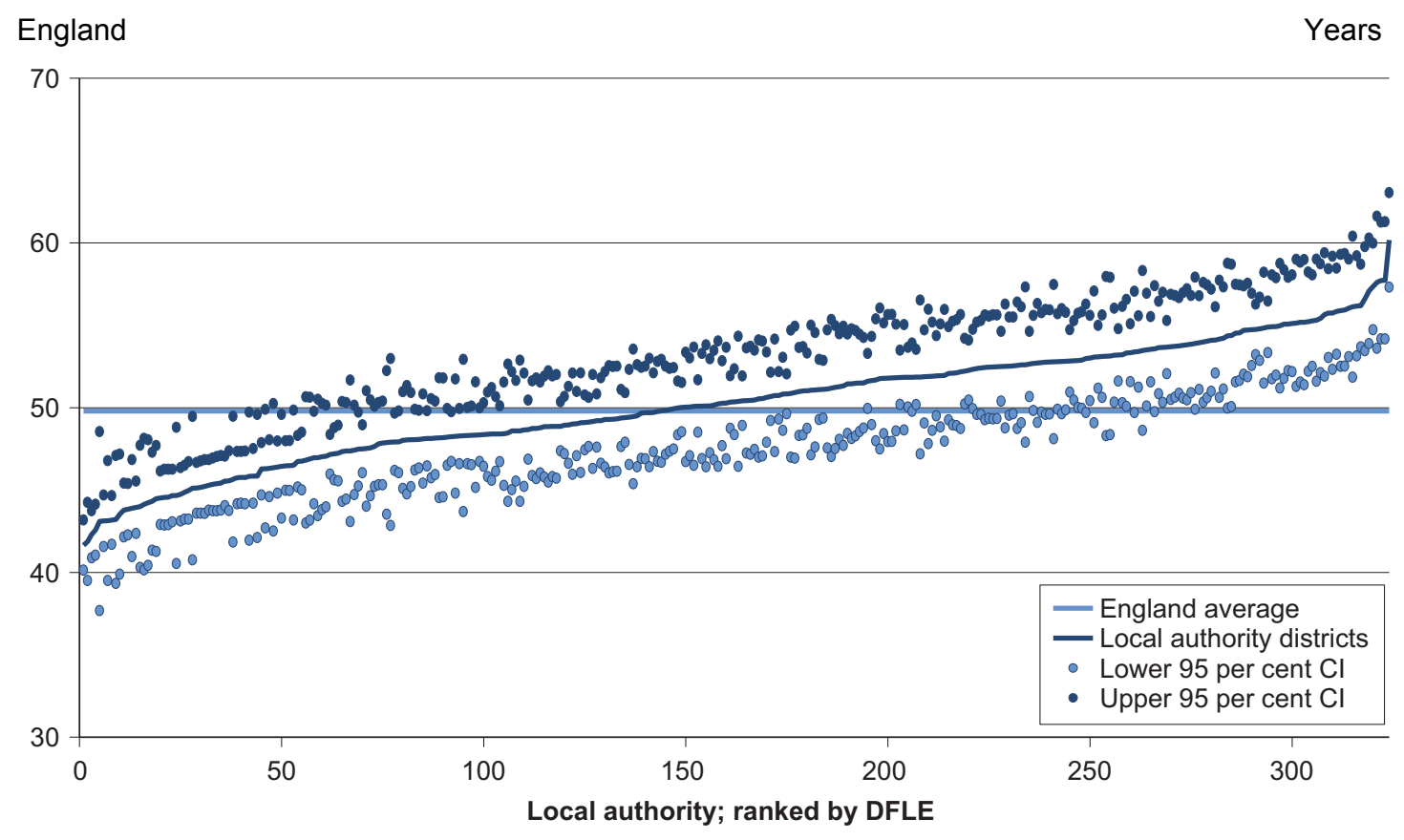

1 Excludes residents of communal establishments except NHS housing and students in halls of residence where inclusion takes place at their parents address

Source: ONS

Fifty-five LAs had estimates of DFLE at age 16 that were significantly lower than the England average of 49.8 years (95 per cent $\mathrm{Cl}, 49.7-49.9$ years). Of these, 54 were in the lowest fifth of LAs when ranked by DFLE, representing 98 per cent of this grouping. By contrast, 81 LAs had DFLE estimates that were significantly higher than the England average; 60 of these were in the highest fifth when ranked by DFLE, representing 74 per cent of this grouping.

Summary statistics for LAs by English region for women in 2006-08 are shown in Table 11 and Figures 9 and 10.

In the North East and North West, 83 per cent and 54 per cent of LAs respectively were in the bottom fifth of all LAs in England when ranked by DFLE. None of the LAs in the North East and just three (8 per cent) in the North West appeared in the top fifth in England. The North East had no LAs with DFLE estimates significantly higher than the England average, while DFLE estimates for three (8 per cent) LAs in the North West were significantly higher. 
By contrast, in the South East and South West just 4 and 8 per cent of LAs respectively were in the lowest fifth in England when ranked by DFLE and 33 per cent and 31 per cent, respectively were in the highest fifth. Three per cent of LAs in the South East and 11 per cent of LAs in the South West had estimates of DFLE that were significantly lower than the England average and 43 per cent and 39 per cent respectively had estimates of DFLE that were significantly higher than the England average.

\section{Table 11 Summary statistics ${ }^{1}$ of DFLE for women aged 16: by local authority districts, 2006-08}

England

\begin{tabular}{|c|c|c|c|c|c|c|}
\hline English Region & $\begin{array}{l}\text { Number in } \\
\text { lowest fifth of } \\
\text { LAs (per cent) }\end{array}$ & $\begin{array}{l}\text { Number in } \\
\text { highest fifth } \\
\text { of LAs (per } \\
\text { cent) }\end{array}$ & $\begin{array}{l}\text { Number } \\
\text { significantly } \\
\text { lower than } \\
\text { England } \\
\text { average (per } \\
\text { cent) }\end{array}$ & $\begin{array}{c}\text { Number } \\
\text { significantly } \\
\text { higher than } \\
\text { England } \\
\text { average (per } \\
\text { cent) }\end{array}$ & $\begin{array}{l}\text { LA with highest } \\
\text { DFLE, years (95 } \\
\text { per cent } \mathrm{Cl})\end{array}$ & $\begin{array}{l}\text { LA with lowest } \\
\text { DFLE, years (95 } \\
\text { per cent } \mathrm{Cl} \text { ) }\end{array}$ \\
\hline North East & $10(83 \%)$ & 0 & $10(83 \%)$ & 0 & $\begin{array}{l}\text { Northumberland, } \\
49.4(47.9-50.9)\end{array}$ & $\begin{array}{l}\text { County Durham, } \\
42.3(40.9-43.7)\end{array}$ \\
\hline North West & $21(54 \%)$ & $3(8 \%)$ & $18(46 \%)$ & $3(8 \%)$ & $\begin{array}{r}\text { Ribble Valley, } \\
57.7(54.2-61.3)\end{array}$ & $\begin{array}{r}\text { Knowsley, } \\
41.7(40.1-43.2)\end{array}$ \\
\hline Yorkshire and The Humber & $7(21 \%)$ & $3(14 \%)$ & $7(33 \%)$ & $4(19 \%)$ & $\begin{array}{l}\text { Richmondshire, } \\
56.1(51.8-60.4)\end{array}$ & $\begin{array}{r}\text { Barnsley, } \\
44.7(43.1-46.3)\end{array}$ \\
\hline East Midlands & $9(23 \%)$ & $7(18 \%)$ & $7(18 \%)$ & $6(15 \%)$ & $\begin{array}{r}\text { Rutland, } \\
56.2(53.1-59.2)\end{array}$ & $\begin{array}{r}\text { South Derbyshire, } \\
44.0(40.3-47.7)\end{array}$ \\
\hline West Midlands & $8(28 \%)$ & $3(10 \%)$ & $5(17 \%)$ & $4(13 \%)$ & $\begin{array}{r}\text { Wychavon, } \\
55.7(52.3-59.2)\end{array}$ & $\begin{array}{l}\text { Cannock Chase, } \\
45.7(41.8-49.5)\end{array}$ \\
\hline East of England & $1(4 \%)$ & $11(23 \%)$ & 0 & $14(30 \%)$ & $\begin{array}{r}\text { Babergh, } \\
57.1(53.9-60.3)\end{array}$ & $\begin{array}{r}\text { East } \\
\text { Cambridgeshire, } \\
45.8(42.0-49.7)\end{array}$ \\
\hline London & $2(6 \%)$ & $4(13 \%)$ & $2(6 \%)$ & $8(25 \%)$ & $\begin{array}{r}\text { Merton, } \\
56.2(53.7-58.7)\end{array}$ & $\begin{array}{r}\text { Newham, } \\
41.9(39.5-44.2)\end{array}$ \\
\hline South East & $3(4 \%)$ & $22(33 \%)$ & $2(3 \%)$ & $29(43 \%)$ & $\begin{array}{r}\text { Tandridge, } \\
60.2(57.3-63.0)\end{array}$ & $\begin{array}{r}\text { Thanet, } \\
44.5(41.3-47.7)\end{array}$ \\
\hline South West & $3(8 \%)$ & $11(31 \%)$ & $4(11 \%)$ & $14(39 \%)$ & $\begin{array}{r}\text { North Dorset, } \\
56.6 \text { (53.4-59.8) }\end{array}$ & $\begin{array}{l}\text { West Somerset, } \\
43.1(37.7-48.5)\end{array}$ \\
\hline
\end{tabular}

1 Percentages are rounded to the nearest whole number

Source: ONS 


\section{Figure 9 DFLE for women aged $16^{1}$ : by local authority district ${ }^{2,3}, 2006-08$}

England

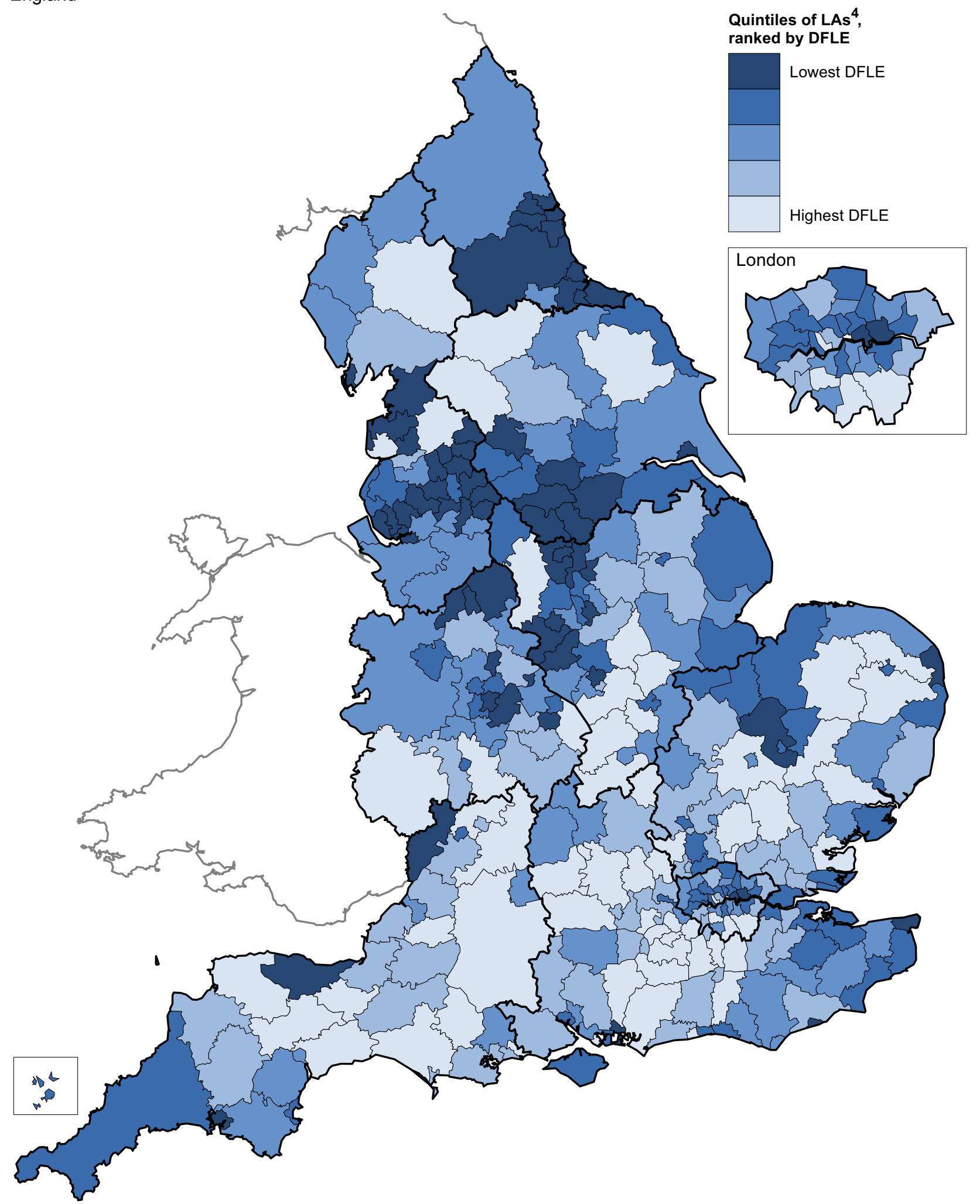

1 Excludes residents of communal establishments except NHS housing and

students in halls of residence where inclusion takes place at their parent's address.

2 After the April 2009 re-organisation.

3 Local authority districts include unitary authorities, London boroughs, metropolitan districts

and non-metropolitan districts in England. Excludes Isles of Scilly and City of London.

4 Each quintile comprises 65 LAs with the exception of the quintile with the highest

Contains Ordnance Survey data DFLE which has 64. 


\section{Figure 10 DFLE for women at age $16^{1}$ : by local authority district and English region, 2006-08}

England

Years

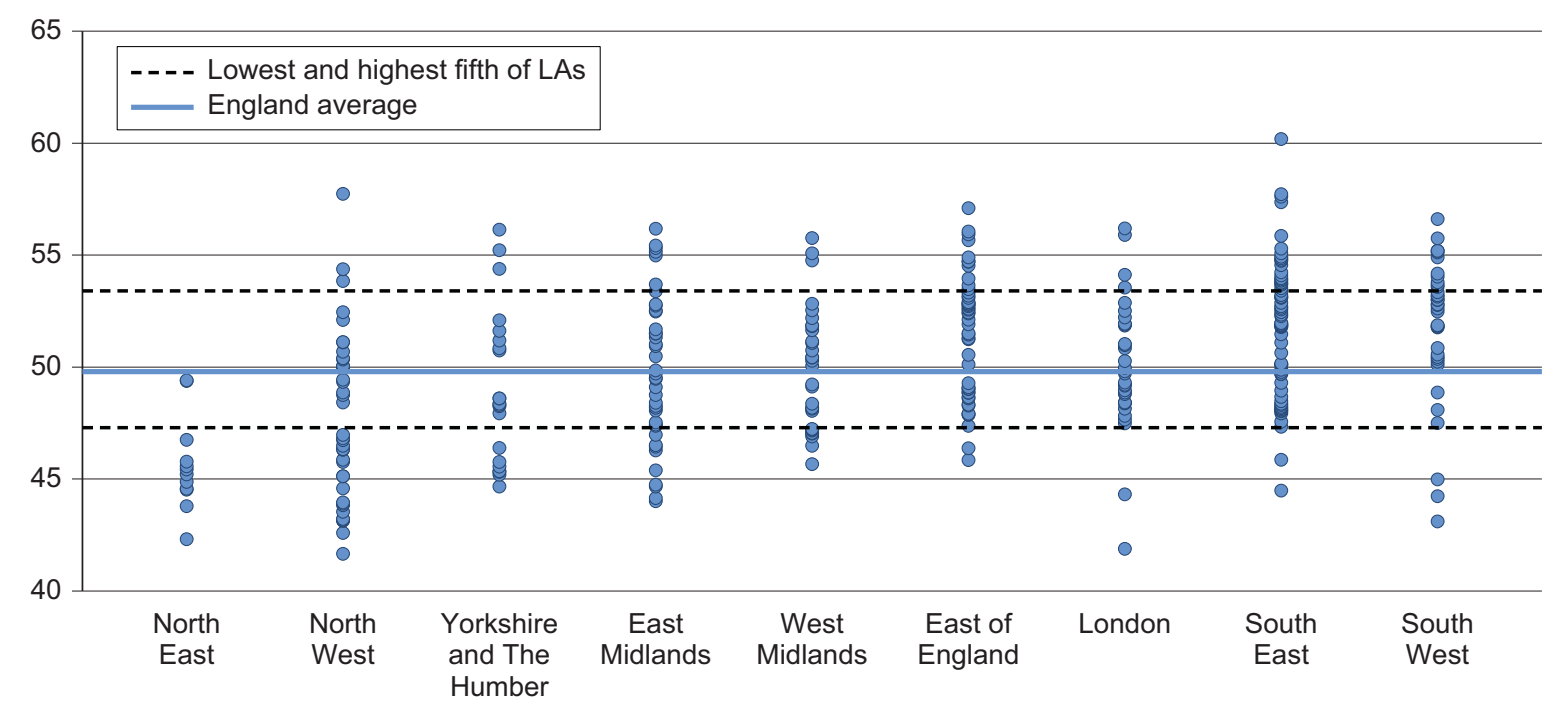

1 Excludes residents of communal establishments except NHS housing and students in halls of residence where inclusion takes place at their parents address

Source: ONS

The top and bottom 10 LAs by DFLE for women at age 16 are shown in Table 12. The data for all LAs can be found in the associated datasets published on-line. 


\section{Table 12 LE and DFLE for women at age $16^{1}$ : bottom and top 10 local authority districts ranked by DFLE, 2006-08}

\begin{tabular}{|c|c|c|c|c|c|c|}
\hline England & & & & & Yea & ars, Per cent \\
\hline Local Authority & Region & LE & DFLE & $\begin{array}{l}\text { Lower } 95 \text { per } \\
\text { cent confidence } \\
\text { interval }\end{array}$ & $\begin{array}{l}\text { Upper } 95 \text { per } \\
\text { cent confidence } \\
\text { interval }\end{array}$ & $\begin{array}{c}\text { Percentage } \\
\text { of life } \\
\text { disability-free }\end{array}$ \\
\hline Knowsley & North West & 63.8 & 41.7 & 40.1 & 43.2 & 65.3 \\
\hline Newham & London & 64.9 & 41.9 & 39.5 & 44.2 & 64.5 \\
\hline County Durham & North East & 65.0 & 42.3 & 40.9 & 43.7 & 65.1 \\
\hline Tameside & North West & 64.1 & 42.6 & 41.0 & 44.1 & 66.4 \\
\hline West Somerset & South West & 69.2 & 43.1 & 37.7 & 48.5 & 62.3 \\
\hline Salford & North West & 63.7 & 43.1 & 41.6 & 44.7 & 67.7 \\
\hline Pendle & North West & 66.2 & 43.1 & 39.5 & 46.8 & 65.2 \\
\hline Liverpool & North West & 63.4 & 43.2 & 41.7 & 44.7 & 68.1 \\
\hline Barrow-in-Furness & North West & 65.3 & 43.2 & 39.3 & 47.1 & 66.2 \\
\hline Burnley & North West & 63.7 & 43.5 & 39.9 & 47.2 & 68.3 \\
\hline England & & 66.4 & 49.8 & 49.7 & 49.9 & $75 . c$ \\
\hline Richmondshire & Yorkshire and The Humber & 67.0 & 56.1 & 51.8 & 60.4 & 83.7 \\
\hline Rutland & East Midlands & 68.5 & 56.2 & 53.1 & 59.2 & 82.0 \\
\hline Merton & London & 67.9 & 56.2 & 53.7 & 58.7 & 82.8 \\
\hline North Dorset & South West & 68.9 & 56.6 & 53.4 & 59.8 & 82.2 \\
\hline Babergh & East of England & 68.4 & 57.1 & 53.9 & 60.3 & 83.5 \\
\hline Reigate and Banstead & South East & 67.2 & 57.4 & 54.7 & 60.0 & 85.4 \\
\hline Runnymede & South East & 67.5 & 57.6 & 53.6 & 61.6 & 85.3 \\
\hline Surrey Heath & South East & 67.8 & 57.7 & 54.2 & 61.3 & 85.1 \\
\hline Ribble Valley & North West & 67.7 & 57.7 & 54.2 & 61.3 & 85.3 \\
\hline Tandridge & South East & 67.6 & 60.2 & 57.3 & 63.0 & 89.0 \\
\hline Range (Tandridge/Knowsley) & & 3.9 & 18.5 & 15.3 & 21.8 & 3 \\
\hline
\end{tabular}

1 Excludes residents of communal establishments except NHS housing and students in halls of residence where inclusion takes place at their parents address

Source: ONS 


\section{Discussion}

The calculation of sub-national HEs between census years has previously been limited to area clusters or relatively large geographical scales. In contrast to the survey data used in these earlier studies, the scale and design of the APS has potential for supplying data with which to derive the DFLE metric and monitor its change at more refined geographical scales such as local authority districts. However, two important limitations in analyses using this source are apparent; firstly, the data coverage is restricted to adults aged 16 years and above; secondly, health data for health expectancy calculation is restricted to the prevalence of LLSI.

While the survey sources are not directly comparable, in both the terminology of the questions asked and in their conceptual basis for classifying disability, each produced estimates of LLSI and DFLE that were of a similar magnitude and pattern across the constituent countries of the UK. This supports the usability of the APS as an appropriate source to estimate the prevalence of LLSI and therefore DFLE in the population.

This analysis observed statistically significant differences in LLSI prevalence in both men and women between the least and most deprived areas; a ratio of 1.7 in men and 1.6 in women. An earlier analysis using General Household Survey (GHS)/GLF data produced similar ratios of the prevalence of LLSI for all ages (Smith et al., 2010b); suggesting analyses of LLSI using the APS are plausible, not unduly influenced by different question terminology and survey purpose, and the scale of inequality in prevalence observed across all ages is adequately represented at ages 16 years and above.

The decline in LE and DFLE at age 16 with each successive quintile increase in deprivation was statistically significant. This supports the presence of significant health inequalities existing between intervening areas of deprivation found in previous analyses based on the Health Survey for England and the GHS/GLF (Bajekal, 2005; Smith et al., 2010a,b). The increase in ratios of LE and DFLE at age 65 between areas provide further evidence that inequalities increase at older ages; the greatest inequalities in longevity and DFLE occur in older men.

While analyses by clusters of deprivation benefit from adequate levels of precision to detect policyrelevant distinctions between the relative health needs of different populations, this approach has more limited value in measuring health improvement arising from localised interventions due to the difference in need between LSOAs within deprivation clusters. Analyses at specific geographical levels provide additional statistics to monitor the effects of interventions designed to improve health outcomes in specific areas and narrow the inequality between them.

In regional analyses, there was a clear north-south divide in LE and DFLE across England; both metrics were significantly lower in the North (North East, North West, Yorkshire and The Humber) compared to the South (London, South East, South West). In comparison with the England average, LE and DFLE were also significantly lower in the North, as defined above, and on the whole significantly higher in the South. This pattern is consistent with previous estimates based on small area analyses using GHS data (Bajekal et al., 2002, Bissett 2002) and Census 2001 data (ONS, 2006; Rasulo et al., 2007; Olatunde et al., 2010). In contrast to estimates of DFLE by area 
deprivation however, there was greater inequality in LE and DFLE at age 16 for men compared with women across regions, but at age 65 , the converse was observed.

The north-south health divide is further emphasised at LA level. Although precision of DFLE at this level weakens, it is striking that 58 per cent of the fifth of LAs with the lowest DFLE for men and women were from northern regions; the North East, North West and Yorkshire and The Humber and only 12 per cent were from southern regions; London, South East and South West. By contrast, in the fifth of LAs with the highest DFLE, 3 per cent were from northern regions for men and 9 per cent for women and for both sexes around 60 per cent of LAs in the highest fifth were from southern regions. These findings are again largely consistent with an earlier study based on Census 2001 data (ONS, 2006) which found a similar north-south divide in the distribution of DFLE at birth for males and females at local authority level.

With the exception of women at age 16 in the East of England, all regions contained LAs with estimates of DFLE that were significantly lower than the England average. In addition, all regions had LAs in the lowest fifth when ranked by DFLE. In each region there were also significant differences between LAs with the highest and lowest DFLE. This finding demonstrates the capacity of APS data to discriminate LAs with the lowest DFLE both within regions and in England, aiding the identification of LAs where this health outcome is in most need of improvement.

It is notable that for men and women, the scale of inequality in DFLE between the highest and lowest estimates doubled with each increasingly detailed geographical unit of analysis. For example, for males the gap in DFLE was 3.5 years between England and Wales, 7.1 years between the North East and South West and 15.6 years between Barnsley and Surrey Heath. These findings support previous analyses comparing the size of health inequality at different geographical scales and which consistently find inequality increasing with progressively finer spatial scales analysed. However, greater geographical refinement hampers comparisons because of precision limitations caused by smaller sample size; the precision of an estimate directly affects how useful it is as a measure to detect significant differences between areas and in monitoring change over time. LAs vary in size across the country and so there was no particular pattern to the precision of estimates by region.

The trade-off between precision and geographical level is a function of sample size and design; while larger samples and un-clustered designs mitigate precision constraints, they are costly to administer. The construction of large datasets through aggregations over longer periods of time is one solution; the other is the potential of the ONS Integrated Household Survey (IHS), likely to deliver sufficient data (a prospective annual sample of 450,000 ) in future years to make a cardinal improvement in the precision of LA estimates during the 2010s. However, both solutions have problems in terms of accrual of data and the relevance of the historic period to which the data apply. While the first annual IHS dataset, relating to 2010, will become available in June 2011, to use this data for health expectancy calculations, mortality data spanning the years 2009-11 is required and the earliest this will be available for analysis is August 2012.ONS intends to start testing the IHS during 2011, with a view to making it the data source of choice for future national and sub-national health expectancies reporting from 2012. 


\section{Limitations of this analysis}

There are a number of limitations to the approach taken here. Firstly, the exclusion of the communal establishment population from the analyses will result in higher estimates of DFLE than would be the case if this population were included. However, inclusion of this population is unlikely to substantially alter the main findings, particularly as the distribution of DFLE based on APS data, largely concurs with previous analyses at birth by LA in England based on Census 2001 data (ONS, 2006). Secondly, the analysis here was restricted to men and women at age 16 and 65 rather than at birth and at age 65. Users are more familiar with estimates of health expectancies from birth than at age 16; however, children are excluded from the APS. There is the option to use alternative data sources, such as the GLF, to estimate the regional mean prevalence of LLSI for children and incorporate these as a proxy measure for the calculation of $\mathrm{HE}$ at birth. Alternatively, there is the option to extrapolate the prevalence data of those aged 16-19 as a plausible proxy for younger age groupings. These approaches will be tested in future analyses.

Finally, the small sample size of the APS at LA level caused estimates of DFLE at age 65 to be subject to proportionally wide margins of error. Analysis at person level rather than by sex is one solution to increase the available sample at age 65.

We intend to explore both the inclusion of the communal establishment and imputed child data as we seek to update this experimental series based on data from the APS in preparation for rebasing ONS national and sub-national estimates of health expectancies on the IHS in 2012.

\section{Conclusions}

This analysis has tested the potential of an aggregated APS dataset to provide prevalence of disability data with which to compute estimates of DFLE at a number of population breakdowns. The inequalities discovered and reported show its usefulness for DFLE measurement.

The magnitude of health inequality increases incrementally with increasing refinement of the spatial scale of analysis, concurring with previous analyses based on the Census 2001. There was a clear north-south health divide in England for men and women and the data presented here demonstrate the scale of the challenge to reduce inequality between regions, LAs and clusters of area deprivation. These data also provide clear benchmarks for area deprivation clusters and regions, but only indicative benchmarks for LA districts with which to assess the impact of policies designed to improve health outcomes and reduce health inequalities beyond the period 2006-08. Sample size limitation for some local authorities militate against the detection of policy-relevant differences from national and regional means for some authorities. 


\section{References}

Adams $\mathrm{J}$ and White $\mathrm{M}$ (2006) 'Removing the health domain from the Index of Multiple Deprivation 2004 - effect on measured inequalities in census measure of health.' Journal of Public Health 28 pp 379-383.

Ashton K and Kent K (2008) 'Annual Population Survey household data sets' Economic \& Labour Market Review 2 pp 44-51

Bajekal M, Purdon S, Woodgate-Jones G and Davies S (2002) 'Healthy life expectancy at Health Authority level: comparing estimates from the General Household Survey and the Health Survey for England.' Health Statistics Quarterly 16 pp 25-37.

Bajekal M (2005) 'Healthy life expectancy by area deprivation: magnitude and trends in England, 1994-1999.' Health Statistics Quarterly 25 pp 18-27.

Bissett B (2002) 'Healthy life expectancy in England at subnational level.' Health Statistics Quarterly 14 pp 21-29.

Gartner A, Farewell D, Dunstan F and Gordon E (2008) 'Differences in mortality between rural and urban areas in England and Wales, 2002-04.' Health Statistics Quarterly 39 pp 6-13.

Jagger C (1996) 'Health expectancy calculation by the Sullivan method: a practical guide.' NUPRI Research paper series No 68, Tokyo.

Mackenbach JP and Kunst, AE. (1997) 'Measuring the magnitude of socio-economic inequalities in health: An overview of available measures illustrated with two examples from Europe.' Social Science and Medicine 44 pp 757-771.

Marmot M (2010) 'Fair Society, Health Lives; The Marmot Review. Strategic Review of Health Inequalities in England post-2010.' The Marmot Review

Morgan O and Baker A (2006) 'Measuring deprivation in England and Wales using 2001 Carstairs scores.' Health Statistics Quarterly 31 pp 28-33.

National Assembly for Wales (2005) The Welsh Index of Multiple Deprivation, Local Government Data Unit, National Assembly for Wales: Cardiff.

Noble M, Smith GAN, Wright G, Dibben C and Lloyd M (2001) The Northern Ireland Multiple Deprivation Measure 2001. Northern Ireland Statistics and Research Agency, Occasional Paper no. 18.

Noble M, Wright G, Lloyd M Dibben C and Smith GAN (2003) Scottish Indices of Deprivation 2003: Summary Report. Crown Copyright, Scottish Executive.

Noble M, Wright G, Dibben C, Smith G, McLennan D, Anttila C, Barnes H, Mokhtar C, Noble S, Avenell D, Gardner J, Covizzi I and Lloyd M (2004) The Index of Multiple Deprivation 2004: Report to the Office of the Deputy Prime Minister, Neighbourhood Renewal Unit: London. 
Office for National Statistics (2006) 'Health expectancies for local authorities in England and Wales, 2001' Health Statistics Quarterly 36 pp 87-96.

Office for National Statistics (2010) 'Health expectancies at birth and at age 65, United Kingdom, 2006-08'. Available at: www.statistics.gov.uk/StatBase/Product.asp?vlnk=12964

Olatunde O, White C, Smith MP (2010) 'Life expectancy and disability-free life expectancy estimates for Middle Super Output Areas; England, 1999-2003. Health Statistics Quarterly 47 pp 33-65.

Rasulo D, Bajekal M, Yar M (2007) 'Inequalities in health expectancies in England and Wales small area analysis from the 2001 Census' Health Statistics Quarterly 34 pp 35-45

Smith MP, Olatunde O and White C (2010a) 'Monitoring inequalities in health expectancies in England - small area analyses from the Census 2001 and General Household Survey 2001-05' Health Statistics Quarterly 46 pp 53-70.

Smith MP, Olatunde O and White C (2010b) 'Inequalities in disability free life expectancy by area deprivation: England, 2001-04 and 2005-08' Health Statistics Quarterly 48 pp 36-57.

Sullivan DF (1971) 'A single index of mortality and morbidity' HSMHA Health Reports 86 pp 347354.

White C and Edgar G (2010) 'Inequalities in healthy life expectancy by social class and area type: England, 2001-03' Health Statistics Quarterly 45 pp 28-56. 